\title{
2. Immigration and Sexuality: Policies and Practices in Switzerland
}

This chapter aims to establish an understanding of the social, political, and economic context and hence the discursive field the participants in this study entered when they came to Switzerland. Chapter 2.1 gives a brief history of immigration to Switzerland, focusing on the interlinkages between the economic development in and immigration to Switzerland on the one hand and the rise of the discourses around Überfremdung (literally 'over-foreignization') on the other. These developments are then differentiated from a feminist perspective. Here, the discussion focuses on dominant ideas about migrant women, which queer migrant women are confronted with as much as their heterosexual counterparts. They are, however, not only targeted by prejudices about $m i-$ grant women, but also face stereotypical ideas about lesbians. Chapter 2.2 accordingly addresses discourses around lesbians in Switzerland. It outlines the history of samesex relationships and the lesbian movement and discusses recent shifts in the legal and social situation of lesbians and gays in Switzerland.

The combined focus of this chapter (on discourses around migrant women on the one hand and lesbians on the other) is not to suggest that the experiences and positionalities of queer migrant women are 'close to,' 'almost like,' or 'a combination of' the experiences and positionalities of heterosexual migrant women or non-migrant lesbians in Switzerland. Instead, the discussion of these two discursive fields points to the very crux of the matter under discussion, which is that these two histories and identities are generally seen as separate: While to date migrant women have almost exclusively been conceptualized as heterosexual, lesbians have hardly ever been thought of as migrants. Thus, Chapter 2.3 discusses the (limited) discourses, policies, and practices that do specifically address the queer migrant subject position, and summarizes the state of scholarly knowledge about queer migration to Switzerland. 


\subsection{Migration to Switzerland}

Looking at the circumstances during different periods of intensified immigration throughout the $20^{\text {th }}$ and early $21^{\text {st }}$ century exposes two dominant aspects of immigration to Switzerland. The first is that Swiss immigration policies, regulations, and practices have chiefly represented instruments to regulate and flexibilize the Swiss labor market (Wicker 2003). Second, the images of immigrants that have emerged from the debates around immigration policies have increasingly revolved around the concept of Überfremdung. In other words, in the past hundred years, immigrants to Switzerland have been welcome as flexible workers, but as people they have predominantly been perceived as a threat to 'traditional' Swiss culture and values (Arlettaz and Burkart 1988, Espahangizi 2019, Jost 1998, Kury 2003, Tanner 1998). This sub-chapter focuses on the rise and consequences of discourses of Überfremdung in Switzerland - as intertwined with economic and political developments in Switzerland and Europe - and the shifts they have been subject to across time and space.

\subsubsection{Migration to Switzerland: Some Basic Facts and Figures}

For several centuries, due to its scarce agricultural and natural resources, Switzerland was a nation of emigrants. It was only in the course of industrialization starting in 1850 that it became a sought-after destination for European immigrants. However, it was not until the late 1880 s that the number of people entering the country began to outnumber the people leaving it (Hoffmann-Nowotny 1995). Although the immigrant population in Switzerland has not developed in a linear fashion, it has continually increased since the 1980s. In 2007, when the fieldwork of this study was ongoing, 1.7 million foreign nationals lived in Switzerland (of a total population of 7.6 million). Among these, the most sizeable diasporas were from Ex-Yugoslavian countries (19\%; the majority of these were from Serbia and Montenegro), Italians (18\%), Germans (14\%), and Portuguese (12\%), followed by French nationals (5\%), Turks, and Spaniards (4\% each). Overall, 85.3 percent of all immigrants were citizens of European countries (two thirds of whom were nationals of EU-17 countries, not including Eastern or Southeastern European countries); 6.4 percent had immigrated from Asia, 3.9 percent from Africa, and 4 percent from the Americas (BFS ${ }^{1}$ 2009).

In 2013, towards the end of the field phase of this study, the immigrant population amounted to 23.3 percent of the overall population in Switzerland (BFS online 2014). This rate, among the highest in Europe, was foremost the consequence of several periods of intensified immigration triggered by political and economic developments, in particular the rise of industrialization, post-war economic growth, and the establishment of the EU (Riaño and Wastl-Walter 2006). High birth and low mortality rates among immigrants and family reunification further increased the number of immigrants: In 2006 about 43 percent of all immigrants in Switzerland had migrated in the context of family reunification, and 26 percent had entered for employment. The reason for this 
development was that immigration related to family reunification was controlled much less strictly than employment-related migration (Riaño and Baghdadi 2007). However, importantly, the high rate of non-Swiss citizens in Switzerland was also a consequence of Switzerland's exceptionally restrictive naturalization practices. Of the 1.7 million immigrants or non-Swiss nationals respectively residing in Switzerland, half had either been born and raised here or had been living in the country for over fifteen years. The low naturalization rate is also a consequence of the ius sanguinis principle practiced in Swiss immigration policy. This means that people who are born to non-naturalized immigrants in Switzerland do not automatically obtain Swiss citizenship, and neither do their children. Immigrants in Switzerland are in principle required to have resided in Switzerland for twelve years before becoming eligible for Swiss citizenship, which represents the longest period in Europe (De Carli 2014). While, in 1998, the Swiss naturalization quota of 1.4 percent was the lowest in Europe, it reached more than 3 percent in 2006 and hence moved close to the average in the European Union (EKM 2012, Riaño and Wastl-Walter 2006). Such low naturalization rates are generally typical for countries with 'guest worker' traditions such as Switzerland, Germany, or Austria, which have prioritized the flexibilization of the workforce over assimilation, forming a purposive relationship between immigration and economic development (IUED 2008). Indeed, in contrast to classical immigration nations such as the U.S. or Canada, Swiss policies have worked to discourage rather than encourage the naturalization of its immigrant population. Immigrants tend to be endured as a necessary evil to secure domestic economic standards rather than being encouraged to become fully contributing members of Swiss society (Riaño and Wastl-Walter 2006). Correspondingly, discourses around immigrants have been marked by prejudices and stereotypes, which in turn have been deployed to legitimize restrictive immigration policies and successfully established immigrants as 'different from the Swiss.' This anti-immigrant stance has fueled a sense of a unique and separate Swiss national identity (Tabin 2004). However, as the Swiss writer Max Frisch famously remarked with regard to guest workers in the 1960s, "Man hat Arbeitskräfte gerufen, und es kamen Menschen" - "Workers were called, and human beings came." This fact has continued to haunt debates around immigration legislation and practices in Switzerland in the late 2010 s.

\subsubsection{The Rise of the Discourse around 'Überfremdung' in Switzerland}

The first significant period of immigration, which started in the late 1870s, brought highly qualified immigrants from the neighboring countries Germany, France, and Austria to Switzerland, who primarily came to support the growing Swiss construction industry. At the same time, there was also a rapidly growing number of less-qualified immigrants, mainly Italian nationals, who also worked predominantly in construction (Hoffmann-Nowotny 1995). At the time, the image of immigrants was positive; they, or their labor respectively, were perceived as indispensable for economic growth and prosperity. Bilateral recruiting agreements with twenty-one countries were established to enable the free movement of labor. Foreign nationals were granted almost equal rights to Swiss citizens (excluding the right to vote), and they could apply for citizenship after only two years of residence (D'Amato 2001, Riaño and Wastl-Walter 2006). This liberal 
policy further fueled the inflow of immigrants, which reached its peak in 1914. In that year, foreign nationals made up 15.4 percent of the total population, the highest rate in Europe at the time (Arlettaz and Burkart 1988, Riaño and Wastl-Walter 2006). In the face of the onslaught of World War I, nationalists and Swiss trade unions started to oppose the liberal immigration policy and began to frame immigrants as a threat to Swiss traditional values, morale, culture, way of life, and, especially, jobs. It is in this changing political climate that the term Überfremdung ('over-foreignization') gained importance, and it proceeded to dominate decades of Swiss policy-making (Arlettaz and Burkart 1988, Jost 1998, Tanner 1998).

The world wars, coupled with the strengthening discourse of Überfremdung, diminished the foreign population by two thirds. During and between the wars, right-wing politicians heated the debate by grounding their arguments in statistical extrapolations rather than facts: While they decried the increase in immigration, the immigrant population was in fact rapidly decreasing due to the economic crisis (Arlettaz and Burkart 1988, Espahangizi 2019, Riaño and Wastl-Walter 2006). This phase is exemplary for Swiss migration scholars' finding that, overall, the actual historical percentages of immigrants hardly correlate with the levels of xenophobia in Switzerland (Skenderovic 2020, quoted in Binswanger 2020).

In 1934, the Bundesgesetz über Aufenthalt und Niederlassung (ANAG) (Federal Law on Residence and Settlement) came into force. It was to remain in effect until 2006 and hence still provided the main legal framework for immigrants when many of the participants in this study entered Switzerland. The new law introduced three categories of immigrant permits: The Saisonnier status, which allowed for a temporary stay of the duration of a working 'season' of nine months and enabled family reunification only after a Saisonnier had worked in Switzerland for three consecutive seasons (this status ceased to exist after the bilateral agreements with the EU came into force in 2002); the Jahresaufenthaltsbewilligung, an annual permit, the extension of which was made contingent on the overall economic situation in Switzerland; and the Niederlassungsbewilligung, allowing for permanent residency in Switzerland. The ANAG marked a paradigm shift on several levels. First, the concept of Überfremdung had now found its way into official language. Article 16 of the ANAG stated: "Officials granting foreigner permits need to take into account the intellectual and economic interests of the country as well as the degree of Überfremdung" (quoted in Riaño and Wastl-Walter 2006:1698). Second, the new legal framework addressed the perceived threat by restricting permanent settlement and by installing legal instruments allowing for a regulation of immigration according to the economic situation in Switzerland. Third, an additional law, the Bürgerrechtsgesetz (B̈̈G) (Citizenship Law), in effect until 2018, moreover significantly restricted access to naturalization; now a minimum of twelve years of residency was required before an immigrant became eligible for Swiss citizenship. In sum, the focus of Swiss immigration policy had shifted from inclusion to exclusion and control (Piguet 2006, Wicker 2003). Crucially, the $B \ddot{u} G$ installed assimilation as a legal requirement for naturalization. Immigrants who were eventually formally eligible for citizenship had to prove that they were "integrated into Swiss society," "familiar with the Swiss lifestyle, morals, and customs," "obedient to the Swiss legal system," and did "not represent a danger to Switzerland's security" (Art. 14 BüG, quoted in Riaño and Wastl-Walter 2006:1699). These vague formu- 
lations opened the door to arbitrariness and discrimination of (changing) stigmatized immigrant groups.

When the economy began to recover after World War II, a fresh need of unskilled and semi-skilled workers arose, triggering a new period of immigration. The new legal framework allowed the government to balance fears of Überfremdung and Swiss employers' need for labor by framing immigration as a temporary phenomenon. A new agreement with Italy, for instance, determined that Italian nationals would need to obtain temporary permits for ten consecutive years or 'seasons' before becoming eligible for permanent residency. From this context, the figure of the Gastarbeiter (guest worker) emerged, who was conceptualized as a Wanderer ('traveler') rather than an Ein-Wanderer (immigrant, literally 'in-traveler' (Baghdadi 2011, Wicker 2003).

Between 1963 and 1967, rising inflation and growing numbers of immigrants prompted the government to issue a number of decrees instructing the private sector to reduce their immigrant workforce. At the same time, Switzerland officially acknowledged for the first time that immigrant workers had become an integral part of the Swiss economy and that established workers should be assimilated. This resulted in measures facilitating permanent residence and family reunification for Italian immigrants (Piguet 2006). However, due to the lack of collaboration of the private sector with the governmental regulations, increasing migration related to family reunification, and high birth rates among immigrants, this package of measures failed to reduce the immigrant population. In the ensuing revival of the myth of an impending Überfremdung, the issue of family reunification was a particularly contested issue. As in many other European countries, family reunification was subsequently subjected to a number of limitations, first in the 1970s and then in the 1990s (Riaño and Wastl-Walter 2006).

Since in the eyes of many citizens the government had failed to address immigration and its associated perceived threats adequately, starting in 1965 a series of Volksinitiativen against Überfremdung were launched to force the government into action (such 'peoples' initiatives' are initiated by interest groups and are directly voted on by the general public). Among these, the Schwarzenbach-Initiative of 1970, launched by James Schwarzenbach, was the most radical. It demanded a reduction of the immigrant population to ten percent in each single Swiss canton, which, if successful, would have entailed the deportation of $300^{\prime} 000$ immigrants residing in Switzerland at the time. The initiative generated a record turnout of 75 percent and was rejected by only 54 percent of the voters. The threat emanating from this initiative and the debate it generated in the media affected immigrants and their families deeply. Indeed, the psychological pressure and sense of being unwelcome that these debates generated still found expression in several family stories told by some of the women who took part in this study, forty years later.

It can even be said that during this post-war period, Switzerland spearheaded the development of modern right-wing populism. As Swiss migration scholar Damir Skenderovic noted in an interview with the online magazine Republik:

Schwarzenbach as a right-wing populist leader figure, as well as the Nationale Aktion, the Republikanische Bewegung, and all the other small parties in their ideological envi- 
ronment indisputably played a leading role in European if not global right-wing populism. Switzerland formed the avant-garde of right-wing populism [...]. (Skenderovic 2020, quoted in Binswanger 2020, my translation)

Skenderovic identifies two crucial ingredients of these historical right-wing discourses in Switzerland that continue to shape right-wing populism internationally to this date: The first is making immigration the absolute center of the political agenda and taking a xenophobic stance; the second is taking an (allegedly) anti-establishment stance. Skenderovic argues that Switzerland was able to take on this leading role in European right-wing populism because it was seemingly less fraught with a fascist past, which allowed "blood and soil" ideas to spread quite unresisted within Switzerland. This stood in contrast to other European countries, where racism and xenophobia were much more strongly tabooed in the years after World War II. This discrepancy becomes particularly evident in the differing degrees of usage of the term Überfremdung post-war: While the term was tabooed in post-war Germany, it continued to be used and strengthened in Switzerland (Skenderovic 2020, quoted in Binswanger 2020).

Following the Schwarzenbach initiative, a number of 'stabilization policies' were introduced that built on quotas and temporary permits. These (and many more policies to be introduced up to the 1990s) were largely a concession to the 46 percent of the population who had voted for the Schwarzenbach initiative. Taking into account the Schwarzenbach supporters seemed to be rewarded by the clear rejection of another anti-immigrant initiative against Überfremdung in 1972. At this time, xenophobia was generally on the decrease, which may be connected to the fact that due to the recession, Switzerland had stopped guest worker recruitment and discontinued temporary permits, effectively exporting unemployment to the workers' countries of origin (Riaño and Wastl-Walter 2006, Wicker 2003). For the first time, pro-immigrant initiatives were launched, advocating facilitated naturalization and the abandonment of the Saisonnier status, but they were massively rejected. When the economy grew stronger in the 1980 , the quotas were raised again. Since Italy and Spain had strengthened their own economies, workers were now chiefly recruited from Portugal, Turkey, and Ex-Yugoslavia, who mainly found employment in construction, the hotel industry, and gastronomy. Migrant women were mainly employed in the latter two sectors, but were moreover engaged in cleaning and care work, where flexible and low-cost workers were increasingly in demand due to the rising number of Swiss women entering the labor market (Han 2003, Karrer et al. 1996, Sassen 1991, Tschannen 2003).

In the 1990s, a number of political developments had incisive effects on immigration to Switzerland and Swiss immigration policies. Italy, Spain, and Portugal had negotiated that their citizens be granted permanent residence after five instead of ten years of temporary work. Further, immigration related to family reunification or education, both of which operated outside quotas and established control mechanisms, was increasing and by the early 2000 s outnumbered work-related immigration (Baghdadi 2011). Third, war broke out in then Yugoslavia, bringing an unforeseen number of asylum seekers to Switzerland. And fourth, voices grew louder in demanding that Switzerland enter bilateral agreements with the EU to establish freedom of movement for EU (and vice versa Swiss) citizens in order to secure the future stability and integra- 
tion of the Swiss economy into the European labor market. The 'stabilization policies' of the 1970s and 1980s built on flexibility, temporary work permits, and seasonal work were therefore no longer fit to address contemporary challenges (Piguet 2006, Riaño and Wastl-Walter 2006).

The governmental commission entrusted with the task of redesigning a new policy had to bridge the gap between the continued fear of Überfremdung on the one hand and perceived economic necessity on the other. This dilemma was 'resolved' by the introduction of the so-called Drei-Kreise-Modell (Three Circles Model). This model was based on the principle of 'cultural proximity' and discriminated between immigrants who were allegedly 'culturally close' to Switzerland and hence assumed to integrate into Swiss society easily, as opposed to those who were allegedly 'culturally distant' and hence expected to have difficulties assimilating (see also next sub-chapter).

In the mentioned Three Circles Model, the innermost circle, whose members were to enjoy first priority in immigration, was reserved for EU and EFTA citizens. The intermediate circle regulated immigration for citizens from the U.S., Canada, Australia, and New Zealand. Citizens from all other countries (including many Eastern European and the Balkan countries) were relegated to the outer circle and were allowed into the country in highly exceptional cases only. Although heavily criticized by human rights organizations and also the Parliamentary Anti-Racism Commission, the Three Circles Model came into effect in 1991. However, the new policy was soon abandoned again in favor of a Zwei-Kreise-Modell (Two Circles Model), which was based on the principle of 'geographical' rather than 'cultural' proximity or distance/difference (although cultural difference remains implicit). This policy further facilitated entry and integration of EU citizens, as well as that of non-EU citizens with skills that were in demand, for instance Indian IT specialists (Riaño and Wastl-Walter 2006). At this time - again fueled by an economic low - political and media discourses arose that revolved around the "integration problem" of immigrants, highlighting perceived problems such as Scheinehe (fictitious marriage), high rates of delinquency, and abuse of the welfare system among immigrants (Piguet 2006). ${ }^{2}$

The Two Circles policy became further cemented in 2002 when the bilateral agreements with the EU came into effect. These granted EU citizens extensive rights in terms of mobility, work, and residency (excluding the right to vote). The Ausländergesetz AuG ('Foreigner Law'), which replaced the outdated ANAG in 2008, further cemented the as an allegedly measurable state. In the new 'Foreigner Law' AuC that replaced the ANAC (see below), the "degree of integration" became a criterion for the issuance or prolongation of residence permits (Kälin 2002). This law conceptualized the "potential to integrate" as including professional qualification, adaptability, language skills, and so on (Art. 23 Abs. 2 / Art. 54 Abs. 2 bis AuC). As the Parliamentary Anti-Racism Commission wrote: "Admission is made contingent on the potential to integrate [...]. The capacity to integrate is, however, not a provable entity; it a is a political criterion. As such, it involves the danger of arbitrary interpretations" (EKR 2003a:2). The EKR saw in the AuC and the Two Circles Model it was based on a continuation of the discrimination between 'good' and 'problematic' immigrants, which continued to rely on notions of cultural proximity and distance (EKR 2003b:16). The AuC was replaced by the Ausländer-und Integrationsgesetz AIC ('Foreigner and Integration Law') in 2019. 
discrimination between citizens of EU countries and the 'rest of the world.' EU citizens were now no longer defined as foreigners, while entry for immigrants from socalled Drittstaaten (third nations) remained restricted to highly qualified individuals, who were moreover only allowed into the country if neither a Swiss nor an EU citizen could be found for the vacant job (Piguet 2006). Immigration of citizens of 'third nations' remained possible in the context of family reunification or education, however, the latter only under specific conditions such as proof of sufficient financial means. This policy was further consolidated when Switzerland joined the Schengen and Dublin agreement. ${ }^{3}$ These two agreements were conceptualized as crucial pillars of the construction of the EU as a common "Area of Freedom, Security and Justice" ("Raum der Freiheit, der Sicherheit und des Rechts RFSR"). ${ }^{4}$ Switzerland had hence become an integral part of what human rights advocates have termed Festung Europa (Fortress Europe) (ElTayeb 2003).

In 2014, shortly after the field phase of this study, the cage of Swiss immigration policy was rattled once more. By accepting the Masseineinwanderungsinitiative (MEI) (Mass Immigration Initiative), Swiss voters, led by the right-wing Schweizerische Volkspartei SVP, mandated the government to reduce and control all immigration. In practice, this necessarily also entails a restriction of the immigration of EU citizens. Since quotas on EU citizens are not compatible with the free movement of persons within the $\mathrm{EU} /$ Switzerland, the bilateral agreements with the EU will now either have to be renegotiated or abolished. The MEI has destabilized the geography of Swiss immigration by abruptly interrupting the trend towards integrating Switzerland into the EU as propagated by the Swiss government. This reassessment of immigration from the EU not only distances Switzerland from the EU, but at the same time also entails a reassessment of immigration from 'third nations.' Some proponents of the initiative argued that should it become difficult to satisfy the demands for qualified personnel from within the $\mathrm{EU}$ - for instance due to restrictions with respect to family reunification - the required skills could easily be obtained from professionals from 'third nations.' The success of the $M E I$ is but the latest demonstration of the longstanding distrust of conservative Swiss voters toward the EU and its fremde Richter ('foreign judges') and is moreover another episode in the dialectic between the government and right-wing forces. In other words, even if official language would have it otherwise, in the eyes of the majority of Swiss voters, EU citizens have remained foreigners. Despite Switzerland's long history of immigration, the refusal to acknowledge Switzerland as an immigration country continues to govern debates around immigrants.

The Schengen agreement removed border controls between EU countries while reinforcing border controls at the outside borders of the EU. The Dublin agreement coordinates asylum application processes, rendering it impossible for asylum seekers to apply for asylum in more than one EU country.

4 The aim to create the EU as a common "Area of Freedom, Security and Justice" was first established in the Treaty of Amsterdam in 1997 and specified in the Treaty of Lisbon in 2007 (Treaty of Lisbon, Article 3 Section 2 EUV and Title V AEUV - Section 67 to 89). 


\subsubsection{A Migrant is not a Migrant: Shifting Geographies of the (Un)desired}

As this brief history of Swiss immigration demonstrates, the symbolic boundary as to who is perceived as what kind of foreigner has been subject to constant shifts, generating ever-new social geographies of immigration. Discourses discriminating between different groups of immigrants have produced a variety of ethnicized/racialized Others that are pitted against the 'Swiss' as well as against each other. As Damir Skenderovic states in the above-mentioned interview:

Of course, the targets change. In the twenties and the thirties it was the Eastern European Jews, in the Sixties the Italians, in the Eighties the Tamils, in the Nineties the Yugoslavians or Ex-Yugoslavians respectively, and since 2001 it has been the Muslims. [...] I do not think it is crucial against which specific group xenophobia is aimed. The focus is always on people who are represented as foreign, as others. (Skenderovic 2020, quoted in Binswanger 2020, my translation)

While the Italians were seen as 'bad' immigrants during the period they were called to Switzerland in great numbers as guest workers in the 1960 s (though North Italians were considered to be better 'assimilable' than South Italians), they have since become the 'good' immigrants capable of assimilation. ${ }^{5}$ As such, Italians are now pitted against new categories of 'bad' immigrants, which especially include nationals from countries from the Global South or Orient (such as 'Muslims' or 'Africans'), as well as nationals from ExYugoslavian countries (who paradoxically were 'good' immigrants at the height of Italian immigration) and Eastern European countries (Wicker 2003, Jain 2018:81-82). Another prominent example for these shifts is the change in the perception of the Sri Lankan diaspora. Although comparatively small in size, the Sri Lankan diaspora has always been highly visible in the media and public discourse. The first (mostly young, male, Tamil) Sri Lankan refugees who escaped the escalating conflict in Sri Lanka in the 1980s were confronted with highly racialized stereotypes, which associated them with drug dealing and delinquency. As one participant in this study of African descent stated, the arrival of Tamils fundamentally changed her life as a person of color in Switzerland, which she ascribed to this group's higher visibility in comparison to earlier immigrant groups. However, the image of the Tamil diaspora has since become more positive. They are now perceived to be successfully integrated into the Swiss economy and to have a 'polite and reserved' behavior (Moret et al. 2007, Herzig 2014). In terms of cultural 'integration' however, the Tamil community continues to be perceived as almost hermeneutically sealed off from the Swiss way of life.

At the same time and in contrast to discourses pitting different groups of immigrants against each other, popular discourses lump Ausländer (literally 'outlanders,' that is, the 'bad,' 'unassimilable' immigrants) together, attributing to 'them' the same negative characteristics no matter their cultural background or biography. Ausländer - usually

However, as the reactivated discourses on Italy, Italians, and Italian 'mentality,' 'culture,' and politics in Switzerland during the Corona crisis in 2020/2021 testify, stereotypical images of Italians persist (see also Soom 2011). 
this generic masculine form is used - are summarily portrayed as unskilled and insufficiently integrated individuals with high criminal energy for whom Switzerland represents the only escape from the dire economic or political situation in their perishing home countries. From these discourses Switzerland emerges as an intact place now becoming threatened by 'floods' of these immigrants with their irrevocably differing cultural values, as well as by their expected exploitation and abuse of the Swiss immigration, asylum and welfare systems.

These examples point to the importance of considering the linkages between the historical emergence of the concepts of assimilation, Überfremdung, and racism. As Rohit Jain (2018) argues based on Michel Foucault's concept of biopolitics, the imagination, legitimation, and material production of European nation-states as they emerged in the 19th century and especially as they developed in the 2oth century crucially rests on a racial and cultural homogenization of its 'people' (Volk). This homogenization can, however, only be achieved through the production and regulation of a non-national Other that remains situated outside nationality and citizenship. The concept of 'assimilation' and of the '(un)assimilability' of certain categories of people respectively thereby functions as an arbitrary gatekeeping criterion regulating who can stay in Switzerland and who cannot, who can be a citizen and who cannot, which lives are, eventually, legitimate and which dispensable. Within this discursive framework, the invocation of an impending Überfremdung in the case of failed assimilation or negligent regulation works as the seemingly objective yardstick against which the success of past, current, or future immigration policies and practices are measured. In other words, "the assimilation logic allowed the state's will - and at the same time forced it - to continuously define, form and protect the national body" (Jain 2018:69, my translation).

In Switzerland, this culturalized understanding of assimilation began to gain importance in the early 20 th century. At the end of the $19^{\text {th }}$ century, naturalization was still propagated as the chief means to preempt the allegedly threatening 'colonization' of Switzerland through immigrants. Assimilation first and foremost meant immigrants' inclusion into the polity and much less their assimilation to alleged 'Swiss' cultural values or mores; such an adaption was deemed to follow necessarily from political inclusion. However, after the turn of the century, culture, ethnicity, and race became increasingly central to the concept of assimilation. The trope of the Swiss Volk gained importance, and this was attributed a specific character and 'spiritual strength' (geistige Stärke). The exceptionalism of this Volk was used to justify its very existence and hence its defense against influence from foreign elements stemming from immigration. The ensuing discourses around 'spiritual over-foreignization' (geistige Überfremdung) marked a crucial shift in how assimilation was conceptualized, moving away from the idea of assimilating immigrants through political participation to the requirement for immigrants to adapt culturally to alleged Swiss values and mores - to the 'national character' of Switzerland. ${ }^{6}$ Assimilation now became organized around a discourse of an impending "denationalization" due to "incoming elements' influence on the morals and spirit [Geist] of the population," which allegedly threatened to "gradually lose its national

6 This spiritual dimension of the Swiss national identity became epitomized in the concept of the geistige Landesverteidigung ('spiritual national defense') between the wars. 
character, its originality, its own ideal, and finally the right to exist as an independent and autonomous people." Thus noted Edmond Boissier, politician and advocate of a stricter Swiss immigration policy in the early 20th century (Boissier 1909:4, quoted in Jain 2018:80, my translation).

This shift from a political to a culturalized understanding of assimilation divided immigrants into those who - allegedly - can, and those who cannot, become assimilated, advantaging "elements" who "can be good Swiss citizens and can entirely assimilate to our customs, mores, and principles" (Boissier 1909:5-6, quoted in Jain 2018:81, my translation). Who is assigned to the former and who to the latter category of immigrants has since remained a matter of political contestation, leaving those in control to decide who can be granted refugee status, what constitutes a legitimate reason to migrate, who can be included into the polity, and so on (Espahangizi 2015:8-9).

In the 1910s and 1920s, politicians moreover successfully linked the idea of assimilability to the notion of race, which was deployed to differentiate between spiritually and geographically neighboring versus more distant and allegedly hence less assimilable peoples. After World War II, when völkisch/racist idioms had fallen into disrepute, these discursive practices were replaced by a "racism without race" (Balibar and Wallerstein 1991, see Chapter 1), within the framework of which racist notions of assimilation were replaced by culturalist approaches resting on the assumption of a gradual (in)compatibility between cultures. Although in contrast to racial boundaries these cultural boundaries were held to be negotiable through assimilation at least to a certain extent, 'culture' within this logic remained a highly monolithic concept that to this date continues to be rooted in essentialist ideas about national character (Jain 2018:85-94).

Later, in the 1960 s and 1970s, assimilation began to focus intently on the surveillance and disciplining of the individual immigrant and each immigrant's personal process of assimilation. In this period, assimilation as a biotechnology moved immigrant subjects' everyday practices, their feelings, even their 'souls' to the center of immigration control, with officials grappling with the question of how an individual's grade of 'inner assimilation' could be measured when only outward behavior could be observed. Against the backdrop of these attempted delineations, there emerged an image of Switzerland that was firmly rooted in monolithic, patriarchal, and heterosexual bourgeois values and ideals (Jain 2018:88ff).

In the mid-1970s, political activities led by immigrant organizations, worker unions, the church, and radical left political parties and organizations marked the beginning of a more multiculturalist counter discourse based on Christian morals and Marxist ideals. This tendency was reinforced by political multiculturalist approaches emerging in the Anglo-Saxon world in the 1980 s and again by the strengthening international debate around minority rights and cultural diversity in the 1990s. However, these efforts evaporated again with the onset of a fresh wave of Überfremdung rhetoric driven by the rightwing party SVP in the 1990s. At least in the bigger Swiss cities, the developments towards a more multiculturalist understanding of coexistence, importantly coupled with the growing commodification of exoticized ethnicities in Western countries, nevertheless allowed for a complication in the assimilation logic, which shifted from a purely assimilationist regime to a regime that to a certain extent also included a multicultural subjectivation logic. Today this allows for a certain degree of visibility of difference for 
some immigrant subjects, at least in some areas of their lives. At the same time, essentialist notions of culture (as the main obstacle to assimilation) continue to dominate debates, laws, and practices around immigration (Jain 2018:148ff).

Jain suggests that in sum the debates around Überfremdung and assimilation have led to the establishment of an "assimilationist subjectivation regime" ("assimilatorisches Subjektivierungsregime") (Jain 2018:66). This regime was, and continues to be, productive of subjects who are then targeted by the state's and civil society's imagination, control, and intervention, and it differentiates between subjects who are willing and able to assimilate and subjects who are held to be 'unassimilable.' Überfremdung and the logics of assimilation outlined in this sub-chapter hence crucially shaped and shape the context the participants in this study entered when coming to Switzerland. As will be discussed throughout this book, legislation, policies, and state and everyday practices grounded in these logics were and continue to be discriminatory of immigrant subjects with respect to many levels of existence including citizenship, political rights, civil rights, criminal law, national security, the job and real estate markets, education, health, family life, identity, and love, to name just a few.

\subsection{4 (Skilled) Migrant Women in Switzerland}

Perceptions of immigrants in Switzerland have not only been classed, culturalized, and racialized but especially also gendered and sexualized. The prototypical image of the male immigrant worker/asylum seeker leaving his homeland to work in Switzerland still persists to date (even though the types of men associated with this image have changed). For a long time, migrant women were only seen as appendices to these men, as their wives and their children's mothers (Morokvasic 1984). Such gendered and sexualized imaginations also manifested themselves in Swiss immigration policy, thereby (re)producing and materializing their very own preconceptions. For instance, for a time, women who entered the country in the context of a family reunification did not obtain a work permit but only a permit to 'reside with their husbands,' and until the late 1970s, only Swiss men were able to pass Swiss citizenship on to their non-Swiss spouses and children, while Swiss women lost their Swiss citizenship when they married a foreigner (Studer et al. 2008). Immigration schemes have, in other words, not only been based on normative assumptions about gender but also about sexuality, reproducing normative ideas about couplehood, marriage, the nuclear family, and reproduction.

In the media and political debates, the figure of the unskilled, financially dependent, ill-integrated migrant wife caught up in traditional gender roles has only been contrasted by a limited range of other victimizing stereotypes of female immigrants such as the Heiratsmigrantin (migrant woman marrying a Swiss citizen), the unskilled exploited female laborer engaged in cleaning or care work, the trafficked prostitute, or the immigrant daughter forced into unwanted arranged marriage or subject to other modes of repression by her family. Within these narrow discourses, in the past years Muslim women in particular have faced the prejudice that they are being oppressed and relegated to traditional gender roles - the antipode to the liberated Western woman (Baghdadi 2011, Gutiérrez Rodríguez 1999, Kofler and Fankhauser 2009, Parini et al. 2012). As is the case for most stereotypes, there is some truth to them: Over the past 
few decades, female immigration to Switzerland has indeed significantly been made up of women entering the country to join their Swiss or emigrated husbands (BFS online $2017^{7}$ ), and many migrant women are indeed subject to precarious work conditions (Dahinden and Stants 2006, Joris 1995, Tschannen 2003) and gender-based violence (Riaño and Dahinden 2010, Neubauer and Dahinden 2012). Among the less known facts about female immigration, however, is that guest worker migration has by no means been exclusively male. Even in the early 1900s, migrant women were already present in the country in considerable numbers, for instance servicing Alpine tunnel construction sites (Joris et al. 2006). After both wars, women migrating to Switzerland from Austria and other European countries outnumbered male guest workers for over a decade, finding employment in the textile and food industries, as well as in private households (Baghdadi 2011). In other words, the women who came to Switzerland in the guest worker era did not only come here to join their husbands but also migrated by themselves to build a better future for themselves. Among them are also some of the participants in this study.

Another lesser-known fact is that male and female immigration to Switzerland has been more or less balanced over the past few decades. At the same time, the proportion of women has varied significantly across different regions of origin: While at the time this research was launched more male than female EU citizens resided in Switzerland, migration from non-EU (especially Asian and Latin American) and Eastern European countries - on which the present study chiefly focuses - had become increasingly feminized. While in 198048 percent of all Latin American immigrants in Switzerland had been women, it was 65 percent in 2005. During the same period the percentage of women among Asian immigrants rose from 46 percent to 55 percent (Riaño and Baghdadi 2007, BFS 2008a). ${ }^{8}$

Swiss migration research has been slow to pick up on these developments and their implications. Indeed, it long conceptualized migration as a male or a gender-neutral phenomenon, and in German-speaking countries in general it was not until the mid1980 s and early 1990 s that feminist perspectives on migration started to take hold in migration studies. This research has made two important contributions to the field: On the one hand, it has salvaged women from Swiss migration history and mapped past and contemporary geographies of women's migrations to Switzerland. On the other hand, more recent feminist migration scholarship has raised the more fundamental question of how gender structures all migration to and from Switzerland (Aufhauser 2000). 9

Within Swiss feminist migration research, analyses of work conditions, labor division, and the Swiss employment market have been a particularly dominant theme.

7 Source: https://www.bfs.admin.ch/bfs/de/home/statistiken/bevoelkerung/migration-integration/in ternationale-wanderung/migrationsgruende.html, downloaded on March 30, 2021.

8 Since the conclusion of this study, this distribution has persisted. In 2019, women made up 45 percent of EU immigrants, 63 percent of Latin American immigrants, and 54 percent of Asian immigrants permanently residing in Switzerland (BFS online 2019).

9 For international foundational work - both Anglo- and Cermanophone - applying a feminist perspective to migration studies, see e.g. Brettell and Simon 1986, Buijs 1996, Han 2003, Karrer et al. 1996, Le Breton Baumgartner 1998, Morokvasic 1983 and 1984, and Morokvasic et al. 2003. 
As already indicated, this research has exposed the precarious work conditions many migrant women (many of them highly skilled) continue to face in unskilled areas of employment such as in the cleaning sector or in factories, in care work, or in sex work. Several participants in the present study, too, were subjected to deskilling and exploitative work conditions. However, the focus of feminist migration scholarship on precarious work conditions came under pressure when it was recognized that this bias unwittingly contributed to the perpetuation of the image of migrant women as passive victims. Subsequently, theoretical perspectives focusing on migrant women's agency and strategies or processes of subjectivation and identification on the one hand and research engaging with hitherto invisibilized migrant women such as for instance highly skilled women on the other has allowed for a more differentiated account of the lives and realities of migrant women in Switzerland.

Seeing that the sample analyzed in this study has unwittingly been strongly biased towards qualified women, the growing body of literature on skilled female migration to Switzerland has been of particular relevance in forging an understanding of the research participants' migration biographies and everyday lives in Switzerland. This research has uncovered that in contrast to prevailing stereotypes about migrant women from 'third states,' the educational level of this particular group of immigrants is, on average, very high. In 2006,40 percent of the female non-EU nationals working in Switzerland had completed tertiary education, compared to 18 percent among their Swiss counterparts (Riaño and Baghdadi 2007, Pecoraro 2005). The bias in the sample towards qualified migrant women can therefore also (but not only!) be interpreted as a manifestation of a more general trend. Yet, it should not be forgotten that this high proportion of qualified women among 'third state' immigrants is partly a direct consequence of recent Swiss immigration policy as described above, which strictly limits migration from 'third states' to highly qualified migrants. ${ }^{10}$

As Yvonne Riaño and Nadia Baghdadi (2006 and 2008) show, the assumption underlying these policies - namely that highly skilled migrant women from non-EU countries will rapidly integrate into the Swiss labor market - is largely unjustified. Many qualified immigrant women, especially those from non-EU countries, face great difficulties when attempting to transfer their professional diplomas to Switzerland and often have considerable trouble finding employment that is equivalent to their training, experience, and skills. This phenomenon is mirrored in other Western countries that have long promoted skilled migration, in particular Canada, Australia, New Zealand, and the U.K. Structural hurdles result in deskilling and an above-average rate of unemployment: In 2007, 9.4 percent of all migrant women in Switzerland were unemployed, versus 5.5 percent among their male counterparts (Baghdadi 2011, BFS 2008a, Gutiérrez Rodríguez 1999, Riaño and Baghdadi 2006 and 2007). ${ }^{11}$

10 In addition to women who apply for a work permit based on their professional qualifications, many women who enter the country in the context of a family reunification are highly skilled as well. This fact further undermines the stereotype of the unskilled and dependent immigrant wife.

11 Riaño and Baghdadi's work focuses on migrant women from Latin America, the Middle East, and Southeastern Europe. Their sample hence greatly overlaps with mine in terms of interviewees' region of origin. 
Due to all of this, feminist migration scholarship is in the process of differentiating stereotypical ideas about migrant women. This work has shown that women who have migrated to Switzerland have different professional qualifications; work in various sectors; are employed, unemployed, or self-employed; migrated alone or with their families; have children or do not; belong to different age groups; are religious or not; and are oriented towards more traditional or more modern role models and labor divisions. However, given German-speaking feminist migration scholars' unanimously constructivist view on gender and their growing engagement with the intersectionality of processes of identification, it is surprising that to date Swiss feminist migration research has hardly engaged with migrant sexualities. The present study therefore is also meant as a contribution to, and extension of, Swiss feminist migration scholarship.

\subsubsection{Asylum}

The upheld 'humanitarian tradition' and especially the accommodation of refugees have been an integral part of the construction of Swiss national identity since the $19^{\text {th }}$ century. It was famously the Swiss citizen Henry Dunant, founder of the Red Cross, who initiated the process leading to the Geneva Conventions, which have crucially shaped the modern understanding of a refugee. At the same time, in the past decades, asylum and especially the fear of its 'abuse' have been among the most intensely and controversially debated issues in Switzerland. Since Switzerland signed the Geneva Convention relating to refugees in 1955, Swiss law had addressed the refugee as an individual. This means that whether a person is to be classified as a refugee or not depends on the "justified fear of persecution." ${ }^{12}$ Only people who are, or 'rightly' fear to be, prosecuted as individuals by the state or non-state actors are hence eligible for refugee status.

Refugees of the Cold War marked the period between 1945 and the late 1970s. First Hungarians (after 1956) and then Czechs (after 1968) fleeing communist regimes were admitted into Switzerland, as were Tibetans and 'Boat People' from a variety of Southeast Asian countries. Particularly European refugees were welcomed in thousands and immediately offered permanent residency. This openness was grounded in the massive anti-communist/USSR solidarity, the need for skilled labor to strengthen the Swiss economy, as well as in the moral obligation to compensate for the rejection of Jewish refugees during World War II (Efionayi-Mäder 2003, Piguet 2006). ${ }^{13}$ Nevertheless, this period of liberal refugee practice is remarkable in the context of the 1960s, as this was when the first initiatives against Überfremdung were launched.

The political crisis in Uganda triggered by President Idi Amin in 1972 and Pinochet's coup d'etat in Chile in 1973 marked the beginning of a new era in Swiss asylum history. The call of the UNHCR to admit Ugandan and Chilean refugees triggered vehement debates in Switzerland. These situations departed from the crises created by the Cold

12 UNO Convention of July 28, 1951, Article 1, Section A.2.

13 A policy (appendix to the Bericht Ludwig) that had been formulated by the Swiss government in answer to a critical report exposing Swiss human rights violations during the war stated that "the [vast majority of] Swiss people will expect and require that the government grant refugees protection" (quoted in Efionayi-Mäder 2003:3, my translation). 
War and as such did not generate the same level of solidarity as before. Correspondingly, xenophobia soon began to find its way into discourses around refugees. In 1981 the first law specifically addressing asylum came into effect, establishing asylum and immigration legislation as two separate systems of admission/exclusion of immigrants. This separation persists to date. A linguistic transition moreover marked a shift in the perception of refugees: In popular discourse, the term Flüchtling (refugee) was replaced by the term pair Asylbewerber/-suchender (asylum claimant/seeker) and Asylanten (person seeking or having been granted asylum), signaling that not all people asking for asylum in fact 'merited' asylum. The asylum law itself established an individual admission procedure, and in the following years, an increasing number of asylum claims resulted in a negative decision (Efionayi-Mäder 2003).

The establishment of the new asylum law was accompanied by intense debates. Since coming into effect, it has been subjected to numerous revisions, establishing asylum as one of the most dynamic and most heatedly contested domestic issues in Switzerland. These revisions have also rendered Swiss asylum policy and practices as one of the most restrictive within Europe, as manifest for instance in the very limited chances to obtain a permanent permit of residence or citizenship, in scarce welfare benefits for asylum seekers, as well as in asylum seekers' heavily restricted access to the labor market. The debates around asylum intensified as between 1980 and 1990 outbreaks of conflicts in Zaire, Turkey, Sri Lanka, and Lebanon brought large numbers of refugees from these countries to Switzerland. In this period, for the first time more than 40 '000 refugees claimed asylum in Switzerland within one year. When, on top of this, the conflict in Croatia broke out in 1991, the increasing number of asylum seekers fueled critical voices, which now increasingly portrayed asylum seekers as simulants without a 'real' - or 'only' an economically motivated - reason to claim asylum. Although the new law drastically reduced the number of asylum claims, the further escalation of the conflict in Ex-Yugoslavia in 1999 once again led to a record number of asylum seekers in Switzerland. For the first time, refugees were only granted a temporary right to stay ("vorläufig aufgenommen" - "provisionally accepted"). Tens of thousands of people from the Balkans had to leave Switzerland again as soon as the Swiss government deemed the situation in Kosovo and elsewhere in Ex-Yugoslavia safe enough for return. This temporary status has since gained importance in Swiss asylum practice and in some years has been granted more often than the full refugee status, which comes with a permit of residence. This diversification of asylum statuses is also owed to the increasingly complex structure of the refugee population. The number of reasons for granting asylum has increased (now for instance including gender-based persecution), as has the number of countries from which applicants reach Switzerland. This renders it difficult for the Swiss government to assess each individual case in context, which has caused asylum procedures of many asylum seekers to last several years and has moreover left the system prone to misjudgment (Piguet 2006).

Over the past few decades, the Swiss asylum system has become increasingly embedded in EU policies. During the early 1990s European countries were essentially engaged in a downward competition as to who could lower their 'attractiveness' for asylum seekers the most in order to redirect asylum seekers to other Western European countries. With the Schengen/Dublin agreements, which Switzerland has also joined, 
EU countries have established a common EU asylum policy and practice. The Schengen agreement, as mentioned before, eliminated border controls within the EU; at the same time, it set up a more rigid and coordinated control of the exterior EU borders, implemented by a common border control agency, Frontex. The Dublin agreement regulates which state is responsible for processing the asylum claim of incoming seekers. This is to ensure that an application is actually examined and that asylum seekers cannot be pushed from one state to another without a proper asylum procedure. Yet the agreement further aims at preventing asylum seekers from applying for asylum in several $\mathrm{Eu}$ ropean countries (Efionayi-Mäder 2003). The Schengen/Dublin agreements hence form crucial building blocks of the strengthening 'Fortress Europe.'

This sub-chapter has traced the historical developments that have led to the current immigration laws, policies, discourses, and practices in Switzerland. These have been critically shaped by increasing discourses around Überfremdung in Switzerland, which have constructed immigrants and asylum seekers as Others threatening Swiss values, mores, and national identity. These discourses have discriminated between 'good' assimilable immigrants and 'bad' immigrants who are thought to be unwilling or unable to assimilate, but the perception of desirable and undesirable immigrant groups has shifted drastically over time. In the context of this study, this means that the date of a research participant's migration to Switzerland has been pivotal with respect to how strongly they were, and have since been, subject to certain stereotypes and mechanisms of discrimination. These positionalities vary depending on the imaginations circulating about research participants' specific national or ethnic 'group' at the time of their entry and thereafter. Further, it has been shown that discourses around Ausländer in Switzerland continue to be grounded in stereotypical images of the immigrant as male and unskilled, though these images have been contested by feminist migration scholars. For the purpose of this study, feminist research engaging with skilled female migration to Switzerland has been shown to be of particular importance, as its analyses contribute to understanding the structures of the migration biographies and everyday lives of the many skilled research participants.

Queer migrant women in Switzerland are not only forced to negotiate dominant ideas about Ausländer but are at the same time confronted with stereotypical ideas about homosexual women. The next sub-chapter accordingly outlines the development and current state of laws, policies, practices, and discourses around lesbians in Switzerland.

\subsection{Lesbians in Switzerland}

\subsubsection{The Emergence of the Homosexual in Europe and North America ${ }^{14}$}

Little is known about relationships among women in Western Europe before the $18^{\text {th }}$ century. Both religious and secular legal texts reaching back to the $13^{\text {th }}$ century suggest that all non-reproductive sexual practices such as same-sex sexual practices, onanism,

This sub-chapter chiefly draws on Caprez and Nay 2008 and Gerodetti 2005. 
anal practices, or bestiality were sanctioned with penalties including the death penalty. These references were highly gendered - as Judith C. Brown notes: "Compared to the frequency with which male homosexuality is mentioned, in canon and civil law, in penitentials and confessional manuals, and in popular sermons and literature, especially after the thirteenth century, the handful of documents which cite the love of women for one another is truly scant" (1989:70, quoted in Caprez and Nay 2008:297).

During the $18^{\text {th }}$ and $19^{\text {th }}$ century, different forms of same-sex relationships among women emerged across Europe. Some women resorted to family terminology to describe the intimate nature of their same-sex relationships. For instance, there were young women who called their much older lovers "mother." These were relationships in which more mature women supported, protected, and taught their younger lovers, who were in turn expected to adore and respect their older partner. Other women who lived together, often their entire lives, would refer to each other as "wife" and "husband," the latter usually more masculine in appearance, the former more feminine. At the same time, romantic same-sex relationships also flowered in more aristocratic circles. The protagonists of these bonds saw these as affinities that involved the exchange of love declarations, kisses, and other physical tenderness but not necessarily sexual acts; the desire involved was seen as more emotional than sexual, and therefore as purer. What most distinguished this era from the following was that same-sex sexuality was generally seen as a matter of personal behavior rather than as a fixed identity. People were not understood to be born as homosexuals but to enter relationships with members of the same or the opposite sex by choice.

The emergence of sexology in the mid-19 ${ }^{\text {th }}$ century radically changed this understanding. Same-sex sexuality was now given a name, homosexuality, which was seen as an innate disorder of sexual drives. This perception turned people desiring the same sex into a type of people and homosexuality into a (pathologized) identity that determined what kind of person a homosexual is. As Michel Foucault famously stated in his seminal analysis, The History of Sexuality: "The nineteenth-century homosexual became a personage, a past, a case history, and a childhood, in addition to being a type of life, a life form, and a morphology, with an indiscreet anatomy and possibly a mysterious physiology. Nothing that went into his total composition was unaffected by his sexuality [...] the sodomite had been a temporary aberration; the homosexual was now a species" (Foucault 1978:43).

Around the turn of the $20^{\text {th }}$ century, sexologists observed, described, distinguished, categorized, and systematized a range of sexual 'deviations.' Within this discourse, Magnus Hirschfeld (1868-1935), a German doctor and sexologist and founder of the first committee to fight for the de-criminalization of sexual acts between men, was the first to argue for a de-pathologization of homosexuality. Like his colleagues, he saw samesex desire as innate and as an integral part of a homosexual's personality, but unlike them, he conceptualized homosexuality as a natural variety of humankind rather than a disorder. Hirschfeld's views were shared by some of his contemporary psychologists and psychiatrists, who were in the process of formulating more general theories of human sexuality instead of focusing on the homosexual variation only. Within this literature, Sigmund Freud (1856-1939) and his successors' psychoanalytical theory remains the most influential body of theory on human sexuality to date. Freud's theory postulated 
that all children possess a bisexual sexual drive that later develops into a heterosexual drive that serves reproduction. Freud's conceptualization of women desiring the same sex as having remained 'stuck' at an immature stage of sexual development and as having failed to develop reproductive sexual drives has since triggered much debate among lesbian and queer theorists, who have attempted to reconfigure female same-sex desire positively (see e.g. Grosz 1994 and 1995). However, overall, surprisingly little has been said about lesbian desire to date.

In the 1940s a further branch of thinking about sexuality emerged: empirical sexology. Its best- known product is the Kinsey Report authored by Alfred Ch. Kinsey (18941956), which was a comprehensive survey about the sexual behavior of 20 '000 men and women in the U.S. In contrast to psychoanalytical theorists, Kinsey and his colleagues assumed that sexual drives were not innate or natural but rather shaped by social norms. Kinsey argued that the hitherto postulated discernibility between homosexual and heterosexual people could not persist in the face of the empirical evidence yielded by his vast survey, which suggested bisexual rather than heterosexual behavior to be the norm in the U.S. Although in Kinsey's own time the consequences drawn from his report in the scientific and political arenas were rather tentative, the study prepared the ground for a change in perspective on human sexuality. Based on Kinsey's insights, empirical sexologists proposed to replace reproductive sexual drives with the ability to have an orgasm as the measure for a healthy sexual life. This development helped to eventually propel the homosexual outside the realm of perversion (at least to a certain extent), which now became primarily reserved for individuals displaying sexual behavior that was tied to sexual violence or unequal power relations, such as pedophilia.

In the 1970s, Second Wave feminists rose against both psychoanalysts' theorization of lesbian desire as immature and empirical sexologists' primacy of the orgasm. Their political project was to wrest the power of defining female sexuality from the overwhelmingly male sexologists. For some women's rights activists, lesbianism came to represent a radical instrument of liberation from patriarchal (i.e. heterosexual) power relations, rather than just a variation in sexual behavior. It was in this context that the term Lesbe/lesbienne/lesbica (lesbian) was first used as a self-conscious and positively connoted political self-definition in Switzerland. To date, this term remains the most common (self-)description for women desirous of the same sex in Switzerland. ${ }^{15}$ Its valuation, however, remains ambiguous and contested as it is used both derogatively in homophobic statements and assertively by many women-loving women. However, since the 1990s, queer theorists and activists have criticized the dominant meaning of the term 'lesbian' for designating a fixed and specific identity that excludes many other forms of female same-sex as well as genderqueer desires, practices, and relationships. As such, they contend that the term 'lesbian' perpetuates the discrimination between normal and abnormal sexualities (and oftentimes the masculine/feminine and male/female dichotomy, as well). These critics have instead called for the development of an

15 Since the completion of the fieldwork for this study, the term 'queer' has gained in importance among sexual dissidents in Switzerland. Current research is analyzing the meaning and usage of the term 'queer' and its relationship to the term 'lesbian' and other self-descriptors related to sexual identity in Switzerland, see e.g. Naef 2020. 
understanding of sexuality that can accommodate its complexity, fluidity, and contradictory nature while also providing leverage for deconstructing the processes that normalize certain hetero- and homosexual sexual identities.

\subsubsection{Same-Sex Policies and Lesbian Spaces in Switzerland}

For a long time, policies addressing 'homosexuals' in Switzerland were a matter of cantonal law, and indeed in many cantons same-sex acts (vaguely named "unnatural indecency") were illegal. ${ }^{16}$ However, even in the cantons where laws explicitly prohibited both male and female homosexual acts, it was almost exclusively men who were prosecuted and convicted on the basis of these laws. The argument for this gender bias brought forth by state agents was that a sexual act necessarily involved penetration, which relegated female desire in general and female homosexual acts in particular to the realm of the impossible. As Christina Caprez and Eveline Y. Nay note: "That women could be sexually active lay outside the imagination of the members of parliament, which is why the figure of the homosexual always had a male connotation. If at all, female sexuality was only debated as passive sexuality in the form of seduction. The law was to ensure that women were to lead 'normal heterosexuality within marriage" (Caprez and Nay 2008:243). Natalia Gerodetti confirms this analysis in her history of sexuality in Switzerland, arguing that to some extent discourses around female samesex desire always remained disconnected from the notion of sexual acts and the figure of the homosexual (Gerodetti 2005:98, quoted in Caprez and Nay:300). This rhetoric tied into the history of a broader discourse in Europe starting in the mid-19th century which tended to deny women's sexual drive, constructing female frigidity as the norm rather than the exception.

After a parliamentary debate spanning several decades, homosexuality eventually became decriminalized on the federal level in $1942 .{ }^{17}$ The two factors that propelled this relatively early liberalization, however, were not necessarily indicative of a liberal attitude. One driving force in these debates was the medical discourse led by virulently political scientists such as Auguste Forel (1848-1931). In accordance with the then-emerging idea of homosexuality-as-identity, these scientists successfully argued that homosexuality should not be criminalized because it was an innate disorder. This 'fact' was not completely absorbed by society as a whole, however. The scientists' arguments were countered by conservative Catholics who saw "same-sex relations as the essential 'grave danger' to public morality, the ultimate corruption of youth and a substantial threat to the 'nation's health' [Volksgesundheit]" (Gerodetti 2005:63, emphasis original). This argument was organized around spatial metaphors depicting the Swiss nation as having "a

The Swiss landscape of homophobia was highly structured. While homosexuality was allowed in most French-speaking cantons (which based their legislation on the more liberal Code Napoleon), most German-speaking cantons grounded their legislation on the Germanic Constitutio Criminalis, which was more restrictive and punished homosexual acts with up to several years of prison (Gerodetti 2005). For a history and discussion of same-sex partnership formalization in Switzerland see also Mesquita 2011, Mesquita and Nay 2013, and Nay 2013.

17 Though homosexual acts with people aged under 20 (heterosexuals: 16 ) continued to be prosecuted. It was only in 1992 that homosexual acts became fully decriminalized. 
'center' whose 'periphery' was being threatened by aberrant sexual practices. If these were allowed to 'spread,' the 'center' would also be 'damaged,' thus higher 'dams' and 'barriers' were needed" (ibid:68). This imaginary of pollution, contagion, and flooding suggests a conceptualization of homosexuality as an acquired disease rather than a congenital disposition. In parliament, these contradictory views - of homosexuality as an innate disorder and as a disease threatening the nation's health respectively - led to a consensual position embracing both stances:

By 1931, homosexuality was still seen as different from same-sex relations, in that homosexuals were exclusively those who had a disposition while, at the same time, the perception was maintained that people could also engage in same-sex practices for other reasons, such as depravity, licentious conduct and too much debauchery. (Gerodetti 2005:97)

Gerodetti therefore identifies a need to complicate the view that the last hundred and fifty years saw a linear shift from homosexuality-as-act to homosexuality-as-identity, arguing that, to this date, this shift has never been entirely successful, neither in Switzerland nor more generally in Europe. The second factor leading to the relatively early liberal Swiss legislation was parliamentarians' anxiety to prevent a development of the kind that had just taken place in Germany, where criminalization of homosexuality had led to a visible and active gay movement. Politicians took this threat very seriously and were anxious not to drag homosexuality as an issue into the daylight unnecessarily.

Once more, female same-sex sexuality hardly figured in this debate. Sexual acts were understood in terms of an active sexual agent, which by implication was male, while women were perceived as unable to perform 'acts similar to intercourse.' As Gerodetti argues, "the men debating female homosexuality simply could not imagine its existence for it fundamentally challenged their perception of female sexuality as passive per se" (ibid:79). As the German criminologist Franz Meixner articulated as late as 1961: "The sexual drive of woman generally awakens only in relations with men and does not unfold, as with men, naturally with elementary force" (Meixner 1961:49, quoted in Gerodetti 2005:80). Indeed, if female same-sex sexuality figured in the parliamentary debate, it was mainly in votes requesting to exempt female same-sex acts from the planned regulation. In other words, female same-sex sexuality was never perceived as threatening as male same-sex intimacy. To the contrary in fact: Parliamentarians saw it as an advisable strategy, be it as a legitimate backup in case of a lack of a man (conceding at least some sort of female sexual drive and agency), or to protect young women from premarital heterosexual contacts, which would damage their most precious and fragile asset: their reputation.

Until the 1970s, in contrast to male homosexuality, female homosexuality was hence hardly an issue discussed in the Swiss public arena. Women living together were not readily perceived as couples, and many women-loving women did not explicitly selfidentify as lesbians or as homosexuals, were often married to men, and were frequently anxious to lead a life as inconspicuous as possible (Rufli 2015, Stefan 1975). They moreover generally faced severe financial restrictions due to conservative role models and 
discriminatory legislation that complicated women's ability to establish a financially independent life. Women-loving women thus often only had the choice between marrying or staying with their parents, which further added to the invisibilization of lesbian love (Baur 2007). ${ }^{18}$

It was only with the sexual revolution and the rise of the homosexual movement in the U.S. following the New York Stonewall riots in 1969 that Switzerland witnessed the formation of a lesbian movement and a broader presence of lesbians in the media throughout the 1970s and the 1980s (although to this date media reports remain strongly biased towards male homosexuals). The TV broadcast Telearena on homosexuality in 1978 was a milestone in this development and bleakly exposed the state of the discussion. Several gay discussants chose to wear a mask. They were supported by their parents and an angry crowd of homosexual supporters, who shouted down the small group of religious conservatives, yet were disturbed themselves by a group of lesbians arguing that the emission was only telling gay men's stories. After the broadcast, one discussant took his life, and several others lost their jobs. However, the broadcast generated a hitherto unknown visibility for homosexual people's concerns, which in the following years eventually led to the abolition of the 'rosa Liste' (pink list - police files on gay men updated on systematic gay club raids) and further decriminalization of homosexual acts in the 1980s (Baur 2007, Fontana 2014).

In 1989, the Lesbenorganisation Schweiz LOS (Swiss Lesbian Organization) was founded, followed by other specifically lesbian organizations and helplines throughout Switzerland. These organizations were instrumental in promoting the thenemerging call for same-sex marriage. ${ }^{19}$ After a number of - mainly French Swiss and urban - cantons had introduced regional legislation allowing for a formalization of same-sex partnerships, the federal Partnership Act enabling same-sex couples to register their partnerships came into effect in 2007. Again, the most outspoken opponents of the law were religious conservatives and Christian political parties defending the institution of the heteronormative family. ${ }^{20}$ The pressure exerted from

18 This is not to imply that, until the 1970s, women-loving women were not politically active. The first known association in Switzerland dates from the beginning of the $20^{\text {th }}$ century and involved bourgeois women's rights activists who lived together in same-sex relationships but did not necessarily self-identify as homosexual. The first women's club, Amicitia, was founded in Zürich in 1931 and mainly addressed a working and middle class audience. Drastic repercussions from the state and negative media reports soon thwarted the strong political drive of the club, and the place transformed into a men-only meeting circle. This process is representative of the invisibilization of homosexual women within coalitions of homosexual men and women before the 1970s (Caprez and Nay 2008, Kokula and Böhmer 1991).

19 Between the late 1960 s and the 1980s, the dominant view in many gay and lesbian circles had been that to call for equal rights with respect to marriage and childrearing was equal to buying into the bourgeois ideal, which would necessarily lead to an ambivalent normalization of homosexual relationships according to the heterosexual nuclear family model (Caprez and Nay 2005:243). This discussion remains salient to this date and is now chiefly discussed under the term homonormativity, which illuminates these developments from an anticapitalist perspective (see Chapter 3.2.1).

20 Today, while the Catholic Church in Switzerland abides by its position that homosexual people should be respected but homosexual acts condemned, Protestant perspectives are more varied and often include liberal views (Caprez and Nay 2008:244-246). 
these groups led the committee of the initiative to strategically exclude all matters regarding reproduction from the planned Act to improve its chances of being accepted by Swiss voters. In contrast to fully equalizing marriage acts in many other countries, Swiss legislation still excludes the possibility of joint adoption (but has allowed for second child adoption since 2018) and prevents access to reproduction technologies. In contrast to heterosexual spouses, it also excludes foreign same-sex partners from facilitated naturalization. It was not until 2021 that the Swiss people voted for the introduction of 'full' same-sex marriage, which will be introduced in 2022 and will eliminate many of the remaining disadvantages for same-sex couples. At the same time, some queer activists and scholars have targeted the increasing normalization of (certain kinds of) same-sex partnerships, as propelled by the Partnership Act and same-sex marriage, for producing further exclusions (Mesquita 2011). For instance, seeking to disturb the proliferating stereotypical representations of homosexuals, a Zürich-based platform for queer feminist activism called sündikat bundles activities that embrace sexual multiplicity and complexity and fosters differentiated discussions around themes like intersexuality, trans, or polyamory.

Despite these developments towards more legal equality and social recognition, queer people continue to be discriminated against in everyday life. Persisting prejudices against homosexuals continue to manifest in certain conservative-religious political discourses, in the many variations of subtle processes of social exclusion, but especially also in the continued infliction of violence against queer people. In the summer months of 2019 alone, 40 hate crimes against queer people were reported to LGBT NGOs in Switzerland, whereas the number of unreported cases is estimated to be high (Pink Cross et al. 2020). ${ }^{21}$ The continued denegation of non-normative sexualities and gender identities further exerts tremendous psychological pressure on queer people, which for instance manifests in a heightened suicide rate especially among young men, and in queer people fearing exposure in their workplace (Schneeberger et al. 2002).

Throughout their history, lesbians in Switzerland have been struggling to carve out spaces for themselves, not only in society at large but also within the political coalitions they entered. Although lesbians had originally been key drivers and integral to both the homosexual and the women's movement in Switzerland, lesbians' needs and concerns were often disregarded both in their political collaborations with homosexual men and with other women as well (Kokula and Böhmer 1991, Lenzin 2000). These struggles were also always about spaces, and accordingly the histories and geographies of lesbian organizations' office spaces, hotlines, meeting venues, cafés, clubs, and websites have been highly agitated and marked by discontinuities, ruptures, dislocations, and displacements. To date, most lesbian venues and cafés often only open sporadically, change locations frequently or discontinue their activities after a relatively short time. This is

21 LCBT = lesbian, gay, bisexual, trans. I use the acronym LCBT throughout this book instead of the more recent, more comprehensive acronym $\operatorname{LCBTIQ}^{+}$(..., intersex, questioning/queer, and more) as it was the acronym that was prevalently used at the time of the fieldwork for this study. Further, in this book the acronym is often used in the context of Swiss LCBT activism in the early 2000 , which was often based on normative ideas about L, G, B, and T 'identities.' 
also reflected in the narratives of queer migrant women who came to Switzerland a long time ago and now reminisce about some of the lesbian spaces - cafés, clubs, and discos - that no longer exist, but which have remained crucial points of reference for them in the story of how they forged their sexual identities. Among the lesbian spaces that still existed at the time the interviews were conducted, the ones that emerged as the most relevant in the narratives were the Frauenraum (women's room) in the autonomous cultural center Reitschule in Bern (one of the very few permanent women's spaces with up to two cultural events a week); the women's disco in the same place; the monthly disco Tanzlelia (which has relocated recently) and Le Bal (which does not exist anymore) in Zürich; and the monthly disco Colours in Basel (ditto). There was generally a great degree of mobility discernible, with interviewees frequently traveling to other cities for these events. Circumstantial evidence suggests that this is a general phenomenon among clubbing lesbians, which is effectively reflective of an all-Swiss lesbian (clubbing) community in the German- and French-speaking parts of Switzerland respectively. Yet, the efforts to establish such venues testifies to the continued demand for women-only spaces, which calls into question the allegedly growing incorporation and recognition of lesbians in mainstream society.

\subsubsection{Swiss Same-Sex Policies in an International Context}

In the past two decades, on a global scale, the changes in terms of sexual citizenship have been dramatic. While some countries have fully opened up the institution of marriage to homosexual couples, others have banned gay marriage, have further criminalized homosexuality, and increasingly prosecute homosexuals. The trend towards legal equalization of homosexual couples was initiated by Denmark, which was the first country in the world to introduce homosexual partnership registration in 1989. Today, most Western European countries have introduced same-sex marriage, others some form of partnership formalization that defines same-sex partners' rights and obligations. In the context of queer migration, these laws have been of particular significance because they also enable citizens or settled immigrants to bring their foreign partners into the country, which in many cases had not been possible before (Binnie 1997). As of 2019, sixteen European countries had introduced same-sex marriage; twenty-one European countries, among them Switzerland, have created possibilities to 'register' same-sex partnerships; ${ }^{22}$ joint adoption by same-sex couples is possible in seventeen European countries; and second parent adoption is available in twenty-one European countries, including Switzerland. Outside Europe, same-sex marriage or partnership registration on a federal level are possible in many Central and South American countries as well as in North America, Australia, New Zealand, and South Africa.

In the context of this study, it should be noted that that Europe has undergone a very rapid transformation in this realm: In the time the interviews for this research were conducted, many of these countries did not yet know such legislation. In many cases, partnership formalizations continue to perpetuate significant discriminations,

22 Note that some countries that have introduced same-sex marriage simultaneously uphold partnership registration, e.g. in the Netherlands. 
which, like in Switzerland, mainly concern immigration, adoption rights, and access to reproductive technologies (see also Chapter 6). Moreover, in ten European countries in Southeastern and Eastern Europe there continues to be no possibility for a formalization of same-sex relationships. What is more, in many countries around the world, homosexual acts are prohibited, predominantly in parts of Africa, the Middle East, Asia, the Pacific Islands, and the Caribbean, with penalties ranging from forced therapy to lifelong incarceration and the death penalty. ${ }^{23}$

The histories of these geographies of homosexualities have neither been linear, nor have they neatly followed the alleged 'West'/'Rest' divide established by homonationalist discourses (see Chapter 3.4). It is telling that some of the figures and facts related to these trajectories will come as a surprise to many readers: Which European reader is aware that South Africa was the first country to unconditionally grant gays and lesbians equal citizenship in its constitution in 1996, followed by Ecuador, Fiji, and Portugal (Oswin 2005a)? Who would have guessed Catholic Spain would be among the first European countries to grant homosexuals full access to marriage? And who is aware that the U.S. has only very recently installed the formalization of homosexual relationships on a federal level, notably long after its neighbor Mexico, which homonationalist discourses in the U.S. notoriously position as underdeveloped?

Against the backdrop of this sexual world map and history, I am critical of the proliferating opinion, also among queer postcolonial scholars, that "there is an unmistakable trend towards greater recognition of human rights for sexual minorities worldwide" (Oswin 2007b:94). I moreover contend that geographies of homosexualities are hard to 'map' in the cartographic sense. While legislation can be mapped, these maps obfuscate the persisting - sometimes extreme - discrimination of homosexuals even in countries where homosexuality is legal or homosexual partnership formalized (see e.g. FRA 2013 for an EU survey on homophobia in Europe; or the current Brazilian President Jair Bolsonaro's fueling of anti-LGBT sentiments). Also, these maps and the texts describing and interpreting them (often unwittingly) contribute to the construction of the dichotomy between the gay-friendly 'West' and the homophobic 'Rest.' As will be discussed in more detail in Chapter 3.4 - and indeed throughout this book -, this is furthermore an often-undifferentiated discourse that particularly fails to take into consideration that the policies and practices around non-normative sexualities have always also been co-structured by postcolonial and neoliberal discourses and practices. Such discourses are (increasingly) serving to legitimize Western states' claims to moral superiority over states in the South and Orient and eventually to vindicate imperialist moves. Thus, although I do not advocate the abolition of such maps, I would like to call for their problematization and better contextualization.

23 Source: www.ilga.org, downloaded on December 22, 2019. The International Association of Gays and Lesbians ILCA regularly provides interactive, comprehensive and well-updated world maps with information about various issues related to sexual citizenship. 


\subsection{Queer Migration to Switzerland}

So far, this chapter has engaged with dominant discourses around migrant women on the one hand and lesbians on the other. This last sub-chapter is concerned with discourses that directly address queer migrants. Chapters 2.3.1 and 2.3.2 offer a synopsis of the legal policies and practices of central concern to 'regular' queer immigrants and queer asylum seekers respectively. Chapter 2.3.3 describes the landscapes of LGBT organizations in Switzerland and discusses the lack of expertise on queer migration that results from this field's structuration.

\subsubsection{Legal Frameworks and Practices I: From 'Härtefall' to 'Partnerschaftsgesetz'}

Although most participants in this study entered the country as 'regular' immigrants - for instance, as holders of a student or work visa -, these permits often expired at some point and required them to pursue alternative strategies in order to be able to stay in the country. For those who had Swiss partners or partners permanently residing in Switzerland, one strategy was to attempt to effectuate family reunification. Accordingly, family reunification emerged as a salient issue in several biographical narratives. Before the Partnership Act came into effect in 2007, the only legal possibility for a Swiss citizen or a permanent resident in Switzerland to bring a non-Swiss (and later non-EU) same-sex partner to Switzerland was the so-called Härtefallregelung, literally 'hardship case regulation' as defined in the ANAG and later the $A u G$, which allowed for an individual case assessment. ${ }^{24}$ As the president of the organization Schwule und Lesben mit ausländischen PartnerInnen SLAP (Gays and Lesbians with Foreign Partners) pointed out in our interview, this procedure required perseverance, excellent writing skills in one of the official Swiss languages, and access to considerable social, cultural, and economic capital in Switzerland. Even then, the procedure rarely met with success. ${ }^{25}$ This expert described 'hardship case' practice in the late 1990 s and the early 2000 s as generally being highly contingent on the responsible cantonal authorities and individual officer. After it became clear that a national Partnership Act was going to be established, the restrictive practices began to loosen. The Partnership Act practically equated the rights of same-sex couples with those of heterosexual couples in terms of immigration (including work and permits of residence), with the important exception that to this date the foreign partner is not eligible for facilitated naturalization like heterosexual married foreign partners are.

Most of the participants in this study who applied for family reunification before the Partnership Act came into effect applied for a permit of residence for themselves or their partners briefly before the Act came into force, when case-by-case assessments had already become more lenient. However, some interlocutors had needed a permit of residence earlier, and, in want of a viable alternative strategy, some resorted to fictitious 
heterosexual marriage. ${ }^{26}$ One of the major problems with the 'hardship case' regulation was that it was a high-risk strategy: Once chosen, the door to fictitious marriage was closed. Against the backdrop of the hurdles connected to 'hardship case' procedures, it was often only informed and politicized people like the president of SLAP himself who chose this path. For singles, for people who are not in a relationship with a Swiss citizen or someone with a permanent permit of residence, and for people who are not able to obtain an independent work permit, the practice of fictitious heterosexual marriage, and now also fictitious same-sex partnership registration was, and continues to be, one of the few possible, though illegal strategies to obtain residency in Switzerland.

While the president of SLAP and lawyers who represent same-sex couples in immigration procedures criticized the arbitrariness with which the 'hardship cases' were handled in the past, the former noted that since the Partnership Act came into effect in 2007, case-by-case assessment - though still a theoretical possibility - has virtually been abandoned in practice. ${ }^{27}$ For the sake of economizing immigration procedure, immigration authorities tend to request that same-sex couples register their partnerships. The president of SLAP considered this a highly problematic development, as it often forces international couples to formalize their partnership after only a short time of knowing each other. As such, immigration procedure in fact often creates the instable relationships it penalizes. Indeed, many accounts generated in this research confirmed this assessment that the Partnership Act does not alleviate all previous concerns, and also raises many new questions, which will be discussed in Chapter 8 .

\subsubsection{Legal Frameworks and Practices II: Homosexuality in Swiss Asylum Procedure}

Three interviewees in this study had claimed asylum in Switzerland, and two of them, a couple, did so explicitly on grounds of their homosexuality. In order to contextualize these cases and to provide a more differentiated understanding of the structuration of the definition of homosexuality in Swiss immigration procedure at large, this sub-chapter outlines the main principles and practices of Swiss asylum procedure with regard to people claiming asylum based on their homosexuality. ${ }^{28}$

26 For reasons of anonymity, the concerned interlocutors did not wish to discuss this issue in a formal interview, see Chapter 8.

27 An immigration lawyer specializing in the immigration of queer people confirmed in our interview that since the introduction of the Partnership Act in 2007, the 'hardship case' procedure has mostly been restricted to cases in which a partner cannot legally divorce in their country of origin, or in cases in which a divorce is not reasonable, for instance due to a common business with a spouse. As a consequence, SLAP virtually closed down its operation after the Partnership Act came into effect, since non-European partners now usually 'just' need to register their partnerships in order to be able to join their partners in Switzerland.

28 I use the terms 'homosexuality' and 'homosexual' in this sub-chapter because queer migrants need to be legible as such by Swiss asylum authorities in order to fall under the laws discussed here; it does not imply that these individuals identify themselves as homosexuals, or should be identified by others as such. 
Three shifts in Swiss asylum policy and practice have been particularly relevant to the legal positionality of people claiming asylum based on their sexual orientation. The first is the inclusion of gender-based persecution in the current Swiss asylum legislation, the Asylgesetz (AsylG). This law came into effect in 1999 and was based on the UNHCR definition of a refugee: ${ }^{29}$

1. Kapitel, Art. 3 AsylG, "Flüchtlingsbegriff":

${ }^{1}$ Flüchtlinge sind Personen, die in ihrem Heimatstaat oder im Land, in dem sie zuletzt wohnten, wegen ihrer Rasse, Religion, Nationalität, Zugehörigkeit zu einer bestimmten sozialen Cruppe oder wegen ihrer politischen Anschauungen ernsthaften Nachteilen ausgesetzt sind oder begründete Furcht haben, solchen Nachteilen ausgesetzt zu werden.

${ }^{2}$ Als ernsthafte Nachteile gelten namentlich die Cefährdung des Leibes, des Lebens oder der Freiheit sowie Massnahmen, die einen unerträglichen psychischen Druck bewirken. Den frauenspezifischen Fluchtgründen ist Rechnung zu tragen.

${ }^{\text {st }}$ Chapter, Art. 3 AsylG, "Definition of the term refugee":

${ }^{1}$ Refugees are persons who in their native country or in their country of last residence are subject to serious disadvantages or have a well-founded fear of being exposed to such disadvantages for reasons of race, religion, nationality, membership of a particular social group or due to their political opinions.

${ }^{2}$ Serious disadvantages include a threat to life, physical integrity or freedom as well as measures that exert intolerable psychological pressure. Motives for seeking asylum specific to women must be taken into account.

As the 2008 Handbuch Asylverfahren (Handbook Asylum Procedure) by the Bundesamt für Migration BFM (Federal Office for Migration, today Staatssekretariat für Migration SEM) specifies, the term "women-specific reasons to flee" more broadly addresses "genderbased persecution" and has been included in the law in order to raise awareness of the specific threats women are exposed to due to their subordinate position in most societies around the world. ${ }^{30}$ The Handbook defines women's positions as typically being shaped by narrow gender roles; relegation to the private sphere; restrictions with respect to self-development in terms of education, work, and financial independence; and legal discriminations. From these disadvantages, a variety of threats emerge, such as sexual violence (BFM 2008:4). In asylum practice, "women-specific reasons to flee" encompass impending female genital mutilation, forced marriage, honor killings, or other experienced or impending violations of the integrity of the body due to social norms, domestic violence, legislation discriminating one or the other gender, one-child policies, or forced sterilization or abortion (BFM 2008, Queeramnesty 2014). The law also explicitly applies to men (though much more rarely in practice), for instance, in cases of sexual abuse, restricted fertility, or social pressure (BFM 2008).

29 This law has undergone recent changes, the last time in 2021, see https://www.admin.ch/opc/en /classified-compilation/19995092/index.html. The articles cited above have remained the same to date. 
The 2008 Handbook explicitly excludes homosexuality ("persecution based on sexual conduct") from the definition of gender-based persecution, based on the argument that it is not the membership of a specific gender that motivates persecution of homosexuals but rather their sexual conduct. At the same time, persecution of homosexuality is considered to be formative of a "social group" as defined in Art. I of the AsylG cited above. In principle, homosexual asylum seekers are thus entitled to obtain asylum, if they can make their individual persecution based on their homosexuality or homosexual acts - or a justified fear of such persecution - 'credible,' and if moving within their country of origin ("innerstaatliche Fluchtalternative") is not feasible (BFM 2008:5 (\$2,1.3), Kälin 1990). ${ }^{31}$

Due to fears of 'floodgate effects,' Swiss asylum practice has tended to frame persecution based on sexual orientation in very narrow terms, nearly conflating it with political persecution (Bertschi 2007). This has led to a low proportion of positive rulings. Although the BFM/SEM did and does not monitor applicants' reasons to apply for asylum statistically (claims based on sexual or gender identity are subsumed under the category 'gender-based persecution'), there is some information available from other sources. The jurist Martin Bertschi, for instance, analyzed all asylum claims grounded in homosexuality between 1993 and 2005. Of the 90 cases he found, only four asylum seekers were granted asylum (Bertschi 2007). Of another 50 asylum claims based on homosexuality that the human rights organization Queeramnesty supervised up to 2010, only four were accepted. As is true for asylum cases in Switzerland in general, the resulting proportion of positive decrees has been significantly below the European average over the past twenty years (Bär 2014b, Ott and Navarra 2019). ${ }^{32}$

The explicit mention of gender-based persecution in the AsylG and the specifications that guide the law's implementation have clearly led to an increased awareness about social issues related to gender and sexuality both in- and outside the government. Attempting to capitalize on this trend, LGBT rights advocates have called for the explicit inclusion of persecutions based on sexual orientation and gender identity in the AsylG. To date, these efforts have been in vain. The same advocates have further argued that, thus far, the "psychological pressure" mentioned in Art. 2 of the AsylG as cited above has been applied inconsistently in the context of asylum claims grounded in sexual orientation (Bertschi 2007, Queeramnesty 2014).

The second shift in Swiss asylum practice that has particularly affected homosexual asylum seekers was the transition from the Zurechenbarkeitstheorie (Accountability

31 The entries in the Handbook addressing persecution base on gender and sexual identity have since been reformulated (see https://www.sem.admin.ch/dam/data/sem/asyl/verfahren/hb/d/hb-d2-d.p df, downloaded on December 22, 2019). However, while in the past few years the understanding of sexuality- and gender identity-based persecution has been refined and asylum officials and legal representatives have become more sensitized towards the challenges sexually dissident asylum seekers face during asylum procedure, refugee status granted on the basis of sexual or gender identity has remained rare (Queeramnesty 2014, Ott and Navarro 2019).

32 For a brief review on the legal situation of lesbian asylum seekers in Switzerland, see also Stichelbaut 2008. 
Theory) to the Schutztheorie (Protection Theory). ${ }^{33}$ Before the latter principle came into effect in 2006, persecution of an individual had to be carried out by the state or a quasistate institution in order to qualify. Under the new Protection Theory, the right to asylum in Switzerland extends to persons persecuted by non-state actors. As a result, a central question asked in asylum procedure today is whether a person experiencing or fearing persecution can receive protection from the state in which the persecution is taking place or impending. In other words, instead of a state's lack of willingness, it is now also a state's inability to grant a persecuted homosexual person protection that makes that person, in theory, eligible for asylum in Switzerland (BFM 2008). This new principle improves the chances of admittance for homosexuals who are persecuted by non-state actors such as family members or religious groups in states where homosexuality is not outlawed. However, Bertschi points out that the Protection Theory has sometimes led to a paradoxical practice. In some decrees, for example, certain states have been deemed willing and able to grant homosexuals protection from persecution even though the laws within that same state explicitly prohibit homosexual acts. In another case, the credibility of a claimant was questioned because he claimed to have denounced homophobic acts of abuse by plainclothes police officers to the police in his home country; Swiss authorities considered this story unlikely as in doing so he would have exposed himself to criminal prosecution (Bertschi 2007:7). Narratives such as the latter may result from the requirement that asylum seekers prove that they sought, but failed to find, protection from authorities. This is a particularly problematic requirement in countries where homosexuals are highly vulnerable to the homophobia of state actors (Queeramnesty 2014).

As these cases demonstrate, to date, the prohibition of homosexuality or homosexual acts in an asylum seeker's country of origin alone does not provide sufficient grounds for obtaining asylum in itself. This means that claimants must prove individually that the state actually also enforces these laws against them personally (just as they must prove being endangered personally in states in which homosexuality is not officially outlawed). Aware that laws against homosexuals are often abused to persecute political dissidents - as, conversely, other criminal laws are abused in order to persecute homosexuals -, it has been notoriously difficult for the Swiss government to assess these situations. Hence, homosexuality-related asylum decrees have been highly susceptible to misjudgment (Bertschi 2007). One frequent argument in negative asylum decrees has been to point to the existence of flourishing gay communities in certain urban centers despite the country's legal and/or social norms that discriminate against homosexuality. According to Swiss authorities, this enables 'inconspicuous' queer people to live their homosexuality without persecution. As Simone Preiswerk (2008) contends, this argument fails to account for the pressure resulting from having to keep one's dissident sexuality a secret. Preiswerk further argues that his pressure is aggra-

33 Bertschi contends that, contrary to the opinions of some politicians and activists, the effect of this change for homosexual asylum seekers has in fact remained rather limited (Bertschi 2007:7). 
vated in the case of same-sex loving women, who are often even more restricted in their mobility and self-development than men (Preiswerk 2008:31). ${ }^{34}$

The third recent development in Swiss asylum procedure affecting the position of homosexual asylum seekers has resulted from a ruling by the High Court of Justice of the European Union (CJEU) in 2013. The decree contains the general statement that somebody fearing persecution based on homosexuality has a right to asylum. But the decree was mainly groundbreaking because it explicitly stated for the first time that the authorities of a receiving European country are not allowed to expect claimants to live their homosexuality in secret in their home country. While the Swiss Justice Minister confirmed that the EU court decree is compatible with Swiss asylum practice, in some cases asylum authorities have still continued to use this so-called 'discretion argument,' that is the argument that certain homosexual people can be sent back to their home countries because no harm will be done to them as long as they keep their sexual identity secret (Queeramnesty 2014). Nonetheless, human rights advocates have recently attested that overall, the asylum procedure for homosexual claimants has improved significantly over the past few years (Schindler 2014).

That being said, the CJEU decree confirmed that prohibitive legislation in the claimant's country of origin does not qualify a priori as persecution. Persecution only counts as such if the laws are enforced, and if this enforcement has targeted the specific individual seeking asylum. This high standard of proof of individual persecution emphasizes the importance of the credibility of a claimant's story, which in the case of homosexuality-based claims often represents the only 'proof of persecution' a claimant can provide. As mentioned in the introductory chapter, this story must be credible and free of contradictions. This represents a difficult precondition, especially in cases in which dissident sexualities had been felt and experienced but not necessarily identified with prior to migration. In this context, another central principle guiding Swiss asylum practice comes into focus. As the BFM officer responsible for gender-based persecution stated in our interview in 2008, assessments were, in theory, solely to be guided by the question of whether claimants could credibly prove they were persecuted as individuals based on homosexual acts or homosexual identity, rather than by the question of whether they were actually homosexual or not. Nevertheless, Bertschi shows in his case analyses that the question of whether someone was really homosexual or not still often played a role in case assessments. For example, the 'credibility' of one claimant was questioned because he did not know of the gay community in his country of origin. In other cases, the lack of knowledge about the laws and penalties for homosexual acts in the home country was interpreted to the disadvantage of claimants. Conversely, 'effeminate' men were automatically deemed more 'credible,' exemplifying a visual economics that continues to guide asylum procedure to date (Bertschi 2007:5, Queeramnesty 2014). ${ }^{35}$ Arguing against this practice, Bertschi suggests that in case

34 In her Bachelor thesis Simone Preiswerk develops guidelines for social workers professionally involved with homosexual asylum seekers. The thesis notably includes a comprehensive documentation of one specific asylum case. required in asylum procedures throughout Europe (Gartner 2015, Ciametta 2017). In the Czech 
assessments, the guiding question should not be whether persecution happens because of homosexual acts or a homosexual identity, or whether an individual asylum claimant identifies as homosexual or not (Bertschi 2007:7). A revised asylum procedure should instead create a solution to the problem that among asylum claimants, people who flee their countries due to persecution for engaging in same-sex practices or for failing to conform to normative gender roles, sexual identities, or sexual practices generally outnumber people who find themselves in a position to explicitly name homosexuality as the reason why they fled (see also Dudek et al. 2007:24).

The question that remains is why asylum seekers applying for asylum based on their homosexuality in Switzerland have almost exclusively been male. This absence is a complex issue to which the present study cannot deliver a comprehensive answer. The data produced in the course of this research seem to confirm the earlier surmise that across many places and cultures same-sex oriented men seem to be more visible and hence more publicly exposed than women (see e.g. Marouf 2008). On the one hand, this may be explained by the almost global relegation of women to the realm of the private. On the other hand, it may be a result of the way female (same-sex) sexuality has been conceptualized. Across time and space, doubts have persisted that women have a sexual drive at all (see Chapter 2.2.2 for the Swiss example in this matter), and consequently that female same-sex sexuality (if considered sex at all) continues to be perceived as less threatening to the patriarchal order than male homosexuality. In many places around the world, one result of such gendered distinctions has been that where legal restrictions apply to homosexual acts, these laws often only address men, or are primarily enforced against men. ${ }^{36}$ Men are hence more often targets of 'formal' and public homophobic persecution. In addition, women generally have considerably less economic, cultural, and social capital at their disposal to migrate. If women do migrate, the spatialities that emerge from conceptualizations of female (same-sex) sexuality work to the disadvantage of female asylum claimants: As a comparative study of refugee decisions from Canada and Australia found, same-sex loving women had difficulties in bringing through their asylum claims since their experiences of sexuality-based violence were seen as "too private." The harm considered "too private" included physical

Republic, for instance, homosexual asylum seekers were shown pornographic films as part of an 'arousal test,' which was only stopped in 2009 (Bär 2014b). In the UK, for a certain period of time, the use of home-made porn as proof for homosexuality became a quasi-standard requirement in asylum claims by self-declared homosexual asylum seekers. A ruling by the High Court of Justice of the European Union (C]EU) in 2014 banned such practices, stating that queer asylum seekers in Europe are no longer allowed to be subjected to homosexuality tests based on stereotypes, or to be forced to provide images to prove their sexual orientation. However, a series of incidences in Austria in 2018 demonstrated that proof of homosexuality guided by heterosexist norms continues to exist in Western Europe. In this case, several queer asylum seekers (men) were turned down for either looking/acting 'too girlish' (which was considered 'fake') or 'too masculine' (hence impossibly 'gay') (see e.g. https://www.independent.co.uk/news/world/europe/austria-gay-man-asylum-ap plication-denied-girlish-lgbt-iraq-a8506091.html, downloaded on May 23, 2020; https://www.tage sanzeiger.ch/ausland/keine-schwulenpornos-kein-asyl/story/10373223, downloaded on January 18 , 2020).

See https://ilga.org/maps-sexual-orientation-laws, downloaded on September 1, 2018. 
and sexual abuse by family members or other private actors, forced marriage, coercive medical or psychological treatment, family isolation, or eviction from the home (Millbank 2002:725). An equivalent gender-sensitive analysis of such asylum claims in Switzerland is yet to be undertaken.

\subsubsection{The Swiss Organizational Landscape: Looking for Experts on Queer Migration 37}

The subject position of queer migrant women marks a typical field of "interlocking systems of oppression" (Collins 1990). The affiliated concept of intersectionality (Crenshaw 1991) has its origins in the intervention of U.S.-American women of color against the dominance of white heterosexual middle class women in the feminist movement. In the Black Feminist Statement, the publication generally considered responsible for breaking the ground for the theorization of the intersectionality of identity, the Combahee River Collective (1982 [1977]) analyzed that women of color are discriminated against in fundamentally different ways than white women. The collective argued that the multiple mechanisms of discrimination they are subject to as women and as Black people cannot be thought of as additional but rather must be understood as interlacing. The concept of intersectionality that emerged from this thinking frames identities more generally as a result of multiple processes of social differentiation and calls for an analysis of their mutual constitution. ${ }^{38}$

The concept of intersectionality is also highly useful for grasping the discursive field inhabited by queer migrant women in Switzerland. The participants in this study were simultaneously marginalized as women, as foreigners, and as sexual dissidents. While other stratifying principles of the social were of course also constitutive of individual interviewees' identifications and experiences, it was primarily their gender, sexuality, and 'migrant' positionalities that were addressed in the formal calls for this research. As such, these three identity categories represented important filters through which this particular field of research was approached, or rather constituted.

As emerges from the two brief histories and geographies of migrant women and lesbians outlined above, the migrant and the lesbian positionality tend to be constructed as separate. This separateness importantly also manifests in the structure of the organizational landscape of organizations engaging with the subject position of migrant women and lesbians respectively. At the beginning of the interview phase for this study in 2005 , this landscape could easily be organized around these three categories - gender, sexuality, and migrant identity respectively (see Figure 1). As these organizations largely emerged from social movements whose proclaimed aim was to name these categories in the first place in order to call attention to the fact that certain social groups are

37 A variation of a part of this sub-chapter was published in the book section "Alltagsräume queerer Migrantinnen in der Schweiz - Ein Plädoyer für eine räumliche Perspektive auf Intersektionalität" in Binswanger et al.'s collection of essays Cender Scripts (Büchler 2009a).

38 Many further contributions to the concept of intersectionality have inspired this study, including Anthias 2001, Anzaldúa 1987, Anzaldúa and Moraga 1981, Collins 1990, 1993, and 1999, Haschemi Yekani et al. 2006, Hull et al. 1982, Klinger 2003, Knapp 2005a and 2005b, Lorde 1982, Lutz 2001, Lutz and Davis 2005, Lutz and Leiprecht 2009, and McCall 2005. 
systematically discriminated against, this categorical structure is not surprising. This structure is also not limited to non-governmental organizations, as these social movements have also fundamentally influenced the organization of the federal government, the political and cultural landscape, cultural spaces, as well as scientific knowledge production in Switzerland.

Figure 1: The Swiss organizational landscape during the research period (2005-2013) mirrors the segregation of identity politics conducted on the basis of gender, sexuality, and race or migrant identity respectively. The lighter the coloring, the smaller the number of organizations or projects addressing the respective intersectional subject positions. $L, G, B, T=$ lesbian, gay, bisexual, trans.

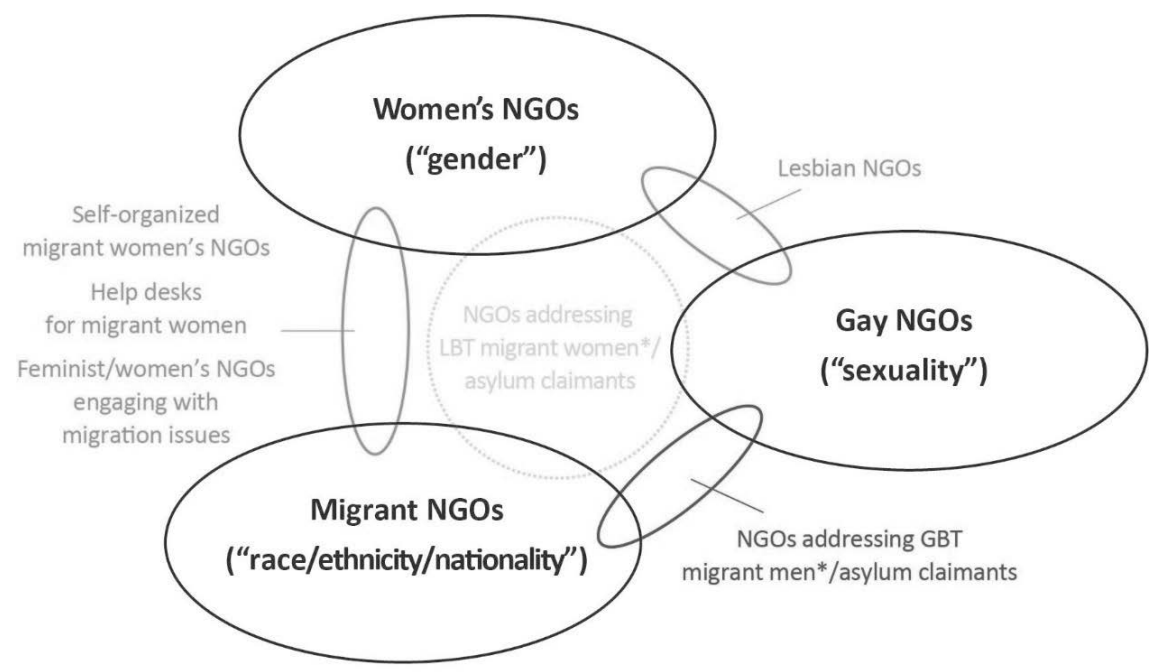

There were only a handful of organizations, mostly short-lived or only sporadically active, that addressed homosexual migrants in Switzerland. Among these, most implicitly or explicitly predominantly address(ed) men. There were some 'migrant groups' initiated by (usually white, non-migrant members) of larger LGBT organizations, such as GayMigs, an initiative by the Homosexuelle Arbeitsgruppe Zürich HAZ, which had closed down shortly before the field phase of this research started. Further, several organizations that in theory addressed both men and women in fact almost exclusively supported men. Queeramnesty and SLAP were two examples in this case. Mostly engaging in activities to improve the situation of LGBT people outside the West, the Swiss branch of Queeramnesty also supported people who seek asylum in Switzerland on grounds of their homosexuality - mostly men. ${ }^{39}$ Among the organizations that engaged with people of all genders and sexualities was the queergender platform sündikat, which in the following couple of years organized some (if few) events specifically addressing queer

39 This latter activity has since become more central to the activities of Queeramnesty (see e.g. Queeramnesty 2014, Ott and Navarra 2019). 
people of color in Switzerland. Under the slogan "The privilege to imagine more," the group stated that "queers resist ("stellen sich queer zu," literally "put themselves queer to") disciplining -> normalization -> programming -> systematization -> regulation -> reduction." ${ }^{40,41}$

SLAP, too, overwhelmingly supported Swiss gay men seeking to bring their foreign partners to Switzerland. Its president estimated in 2007 that 80 percent of their incoming requests were from men. ${ }^{42}$ The likely explanation for this gender bias can be found in the statistics that have since emerged following the introduction of the Partnership Act in 2007: Generally, there were roughly double as many men as women who registered their partnerships, annually about 1'000 men and 500 women. Of these, on average 75 percent of the women but only 58 percent of the men were Swiss citizens. Of these non-Swiss citizens, 60 percent of the women but only 40 percent of the men were European citizens, for whom immigration into Switzerland is mostly uncomplicated thanks to Switzerland's participation in the European agreements concerning the free movement of people. Swiss men hence much more often registered partnerships with non-European citizens of so-called Drittstaaten, whose immigration was, and especially had been before the Act, considerably more complicated, particularly if they were not from Western countries such as the U.S. A representative example illustrates these numbers: In 2014, 102 male but only 22 female citizens from African, Latin American and Caribbean, Asian, and Oceanian countries registered their same-sex partnership in Switzerland. Among them were 56 men and 17 women from Latin American and Caribbean countries; and 38 men and two women from South East Asian countries (BFS online 2007-2018).

To return to the organizational landscape in Switzerland: At the outset of this research I was unable to locate self-organized groups by queer migrant women in Switzerland who practiced an identity politics explicitly grounded in the experience of queer migrant women (i.e. as women simultaneously targeted by racism, heterosexism, and sexism);

40 Source: http://www.suendikat.ch, downloaded on August 13, 2013 (my translation).

41 As discussed in the introduction, a number of groups have emerged since that address the positionality of queer migrant people, such as for example Bla*Sh or Queer Migs. Bla*Sh-Black She describe themselves as a "network of Black women living in Cerman-speaking Switzerland. We live straight or queer, with or without children, some of us have grown up exclusively in Europe, others have lived on other continents, and what binds us together is the experience of being perceived as 'Black' and the Afro hyphen: All of us have at least one Black parent, we are, in other words, all 'of African Descent' in the broadest sense of the word. We aim for social, cultural and political empowerment and are looking forward to your message and participation!" (Source: https://www.fa cebook.com/pg/NetzwerkBlackShe/about/?ref=page_internal, downloaded on December 26, 2019, my translation). QueerMigs, founded by two queer migrant women in 2013, is "a project for LGBT people who migrated to Switzerland and for local people that want to meet the newbies. Come in, sit down, enjoy time together with us." In collaboration with Queeramnesty, QueerMigs has also established a regular "Welcome Café for LGBT refugees." Source: http://queermigs.tumblr.com/, downloaded on September 18, 2013; www.queermigs.ch, downloaded on December 26, 2019.

42 As discussed above, SLAP virtually closed down operation after the introduction of the Partnership Act, which facilitated the immigration of registered non-Swiss citizens. 
nor did there appear to be websites, helplines, or regular cultural events that specifically addressed this subject position. ${ }^{43}$ This absence stood in contrast to other - also small - European countries where organizations already existed by and for queer migrant women. ${ }^{44}$ The disparity was even more glaring when comparing the situation in Switzerland to the organizing in many North American cities. For example, in 2005, in the city of Toronto alone there were twenty-four LGBT groups addressing members of a specific ethnicity; six addressing members of specific linguistic communities; and eleven addressing followers of specific religions (Smith 2005). ${ }^{45}$ The recent flurry of publications on racism in Switzerland is now beginning to identify the reasons for the relative dearth of such activisms - and generally anti-racist activism - in Switzerland at the time. These analyses suggest that until recently the political and social landscape in Switzerland rendered it almost impossible for immigrant people to address racism. As the longtime anti-racism activist, Halua Pinto de Magalhães, stated in an interview with the newspaper Der Bund about anti-racist activism a few years ago: "Wer damals öffentlich über Rassismus sprechen wollte, nahm dieses Wort kaum in den Mund. Er sprach von Integration" - "Whoever wanted to speak about racism at the time refrained from using this term. He spoke of integration." ${ }^{46}$ His statement supports critical race scholars' and activists' diagnosis that Switzerland continues to identify, and become identified, as a space free of racism, which creates a space in which racism exists but is not addressable (see Chapter 1). However, Pinto de Magalhães and other activists and scholars have initiated a change in the past few years by addressing racism in Switzerland increasingly openly and loudly. These voices were further strengthened by the arrival of the "Black Lives Matter" movement in Switzerland in 2020. The reasons as to why such a change has become possible are diverse and include: The 'second generation' - the children of immigrants - has grown up and claims citizenship with more ownership than their parents, who were often strictly disciplined into 'assimilating' and 'integrating; Switzerland has become more diverse; the internet and social media allow for more access to alternative representations and anti-discriminatory contents; the continuous strengthening of the far right has triggered reactions from the other side of the political spectrum; and the "Black Lives Matter" movement has increased sensitivity for racist cultures. As Walter Leimgruber, the president of the Eidgenössische Migrationskommission (Federal Migration Commission), stated in an interview published in the 2018 biannual report by the Fachstelle für Rassismusbekämpfung (Federal Service for Combating Racism): "We can see now that criticism of racism and discrimination has really arrived in society, and that migrant men and women and their descendants are demanding their place in society" (Fachstelle für Rassismusbekämpfung 2018:173, my translation). At any

43 An exception was the lesbian community site www.shoe.org, which used to offer chat channels in many European languages. However, shortly after the beginning of the interview phase, the language choice was reduced to English and Cerman.

44 E.g. ViennaMix and MiCay (Vienna), LesMAus (Linz), LesMigraS (Berlin), the SAFRA Project (London).

45 While groups addressing certain nationalities, ethnicities, or religions do not exclusively address people who have immigrated as adults (who this study focuses on), these activities generally established a very visible and diverse landscape of intersectional LCBT/migration identity politics. See e.g. https://www.derbund.ch/bern/integration-ist-ihnen-nicht-genug/story/20511595, downloaded on June $4,2020$. 
rate: At no time was there any validity in the argument I was often told at the outset of this research project that there were probably simply not enough queer migrant women to form such groups, seeing that Switzerland was such a small country. ${ }^{47}$

In the process of looking for informants, I focused on organizations addressing lesbians, organizations addressing migrant women, and, where existent, organizations addressing queer migrants. This search exposed a profound lack of experience with, and knowledge about the experiences of queer migrant women in all of these organizations (see also Büchler 2009a, and Chapter 7 in this book). In the following, I use the case of lesbian organizations to exemplify this lack of expertise.

As the president of the LOS - the largest lesbian organization in Switzerland - stated in our interview in 2006, migration was not planned to become a priority in Swiss lesbian identity politics in the following years. Instead, most of the limited resources were going to be allocated toward advancing the legalization of adoption and artificial insemination for lesbian couples. ${ }^{48}$ Nevertheless, the LOS positioned itself as an advocate for queer migrant women, as for example manifests in the fact that its representatives repeatedly participated in round-table discussions addressing queer asylum, where they spoke as experts on the issue. This expertise was, however, not grounded in experience with or knowledge about the realities of queer migrant women (be they asylum seekers, regular immigrants, or Sans Papiers). The president of the LOS, who had herself acted as a discussant on such podiums, admitted in the interview to not knowing any queer migrant women personally.

As outlined in the introduction to this study, political debates on queer migration have largely focused on queer asylum, which has remained the discursive space in which queer migrants in Switzerland have become most visible (men, mostly). However, these discourses may unintentionally turn against and invisibilize the queer migrant subject. Revisiting the statement discussed in the introduction (quoted below in a slightly more extensive version) reveals how queer migrants are inadvertently instrumentalized to promote domestic LGBT issues while at the same time projecting homophobia onto an alien Other:

One common reaction to this research project had been that it was 'too specific,' addressing a very small group of people only. To be clear, I do not believe that the number of people a research project addresses in any way correlates with its significance, particularly seeing how dominant discourses often project core social issues onto the bodies of sometimes very small minorities, at the same time producing and excluding these minoritarian subjects. Nevertheless, I suspect that the number of queer migrant women in Switzerland is being grossly underestimated (by those who even think of estimating it). Evidently, any attempt at an estimate is based on several highly contestable assumptions, such as assuming a 'homosexuality rate' of five to ten percent, or the representation of this percentage in diasporic communities, especially among female immigrants. However, even a most conservative estimate places a five-digit number of queer migrant women in Switzerland.

48 Interview with the president of the LOS, October 20, 2006. Until very recently the LOS has largely remained true to its announced negligence of migration-related issues. 
Das Thema Homosexualität muss [beim Asylverfahren] in den ersten achtundvierzig Stunden auf den Tisch. Viele, die das Wort 'schwul' das Leben lang noch nicht in den Mund genommen haben, weil sie sich nicht getraut haben, und dann sollten sie plötzlich Klartext sprechen, oder? Wir wissen alle, die sich selber mal geoutet haben, wie schwierig das ist.

[During the asylum procedure], the issue of homosexuality has to be laid out within forty-eight hours. ${ }^{49}$ Many of those who have not uttered the word 'gay' ever before in their lives because they were afraid to do so, and then they are suddenly expected to speak [about it] plainly, is that right? All of us who have come out ourselves know how difficult this is.

-President of a lesbian organization on a podium on queer asylum hosted by the Swiss Socialist Party in Bern in September 2006

Asylum seekers - as the term "gay" (in German "schwul" has a distinctly male connotation) indicates, they are presumed to be male - are assumed to be 'gay but closeted.' They are depicted as already being aware of their gay identity internally, but not having communicated it yet. The only thing keeping them from "speaking plainly" is their homophobic cultural (ex)context, from which they are simultaneously separated by their clandestine homosexuality. Assuming a collective global gay identity and experience ("us"), the Western trope of 'coming out' is projected onto the Other, who in reality may or may not think of (homo)sexuality as an identity, and who may or may not be aware that the speech act of 'coming out' is a requirement for becoming legible as a homosexual and hence as a potentially persecuted person by Swiss asylum officials. Queer postcolonial social anthropologist Martin Manalansan has identified the trope of the 'coming out' as central to processes of racializing, gendering and hence disciplining queer people of color: "Non-Western practices are marginalized and cast as 'premodern' or unliberated. Practices that do not conform with Western narratives of development of individual political subjects [such as especially the 'coming out'] are dismissed as unliberated or coded as 'homophobic'" (Manalansan 1997:486). In consequence, the 'real' queer migrant subject (whether asylum seeker or regular immigrant), disappears vis-àvis the construct of the paradigmatic (male) homosexual asylum seeker. Equating "our" experiences with the imaginary asylum seekers' moreover overlooks the discrimination specifically aimed at migrants and asylum seekers.

As discussed in detail later (see Chapters 3.4.4 and 8.2.3), it is the promise of highly scandalized human rights news that lures some LGBT rights organizations to resort to such victimizing stereotypes of queer migrants. As Alice Miller states, "asylum claims

49 In order to establish 'credibility,' it is vital that asylum seekers establish their Asylgrund (the reason why they are claiming asylum) within the first forty-eight hours of their arrival in Switzerland. If the Asylgrund is changed after this period of time, this crucially diminishes the chances of obtaining asylum. The 2008 Handbook Asylum Procedure of the BFM acknowledges the possibility that seekers may withhold the reason for their persecution at first in cases in which they have been raped or otherwise traumatized or have been subject to considerable psychological pressure in the context of gender-specific persecution. Accordingly, it states that the contradictions in narratives arising from such experiences should not be read as infringing credibility per se (BFM 2008:20 $(\$ 2,4.4)$ ). How to handle this question effectively in practice remains a contested issue (Queeramnesty 2014). 
are visible victories, rare in the human rights world" (Miller 2005:162, see also Berger 2009 and Espahangizi 2015). ${ }^{50}$ More recent campaigns by Swiss LGBT organizations have furthermore located the problem of homophobia in Switzerland as residing within immigrant communities themselves (Mesquita 2011:222-231, Mesquita and Purtschert 2016). Homophobia is thus transferred to an external Other, rendering it difficult to sustain criticism against the continued homophobia and structural discrimination within Switzerland.

Swiss LGBT organizations hence play a highly ambivalent role in debates around migration. This observation is not meant to berate the hugely important work done by these organizations in any way. Rather, it is to point to the importance of reflecting on the effects of discourses and practices that project Swiss/Western homosexual subjects' topoi onto non-Western sexual Others and homophobia onto non-Western cultures.

To conclude this reflection on the intersectionality of the 'field' of this study: Entering the 'field' via organizations that were seemingly situated 'close' to the intersectional subject position that I was interested in, queer migrant women, in fact resulted in a demonstration of intersectionality theorists' argument that social categories cannot be thought of as additional. The lack of organizations, projects, and institutions addressing queer migrant women resulted in a lacuna of knowledge about queer migrant women's biographies, social networks, familial situations, work situations, living conditions, experiences, concerns, and everyday lives in Switzerland. Although the situation has since seen change due to the recent foundation of groups explicitly addressing queer people of color (see Chapter 1), their multiple discriminations and, tied to these, their continued far-reaching invisibility persist. The present study addresses this gap in knowledge, at the same time heeding Natalie Oswin's cautionary note that "[t]hrough looking intently at the other, we may nonetheless learn nothing about 'them.' At the same time, we learn nothing about 'us.' [...] If we continue to look only outward, we will focus on the ways in which the western queer model fails to fit in the non-West at the expense of exploring the ways in which it also fails to fit in the West" (Oswin 2006:788).

In sum, this chapter has shown that while there exists extensive literature on immigration to Switzerland; while there is a quickly growing field of research engaging with women-specific issues in the context of migration; and while there is some, although still scant, scientific knowledge on the history and lives of lesbians and people of color in Switzerland, queer migration, and especially female queer migration, to Switzerland remains a very open research field. Although scholarly engagements with postcolonial configurations of sexuality and migrant sexualities are beginning to emerge, these discussions have remained side remarks rather than central concerns (Caprez and Nay 2008, Mesquita 2011, but see Huotelin 2013). Also, in contrast to other European countries (e.g. LesMigraS 2012 in Germany or the Safra Project 2002 in the U.K.), there have, to my knowledge, been no studies commissioned or carried out by non-governmental organizations that have illuminated queer migrants' lives and needs in Switzerland. For the conceptualization and theorization of this research I thus now turn to Anglophone queer migration and queer geographical scholarship. 
